\title{
Did the Construction of the Bhumibol Dam Cause a Dramatic Reduction in Sediment Supply to the Chao Phraya River?
}

\author{
Matharit Namsai ${ }^{1,2}$, Warit Charoenlerkthawin ${ }^{1,3}$, Supakorn Sirapojanakul ${ }^{4}$, William C. Burnett ${ }^{5}$ and \\ Butsawan Bidorn 1,3,*(D) \\ 1 Department of Water Resources Engineering, Chulalongkorn University, Bangkok 10330, Thailand; \\ Matharit.Na@student.chula.ac.th (M.N.); 6270335121@student.chula.ac.th (W.C.) \\ 2 The Royal Irrigation Department, Bangkok 10300, Thailand \\ 3 WISE Research Unit, Chulalongkorn University, Bangkok 10330, Thailand \\ 4 Department of Civil Engineering, Rajamangala University of Technology Thanyaburi, Pathumthani 12110, \\ Thailand; ong_rit@yahoo.com \\ 5 Department of Earth, Ocean and Atmospheric Science, Florida State University, Tallahassee, FL 32306, USA; \\ wburnett@fsu.edu \\ * Correspondence: butsawan.p@chula.ac.th; Tel.: +66-2218-6455
}

check for

updates

Citation: Namsai, M.;

Charoenlerkthawin, W.;

Sirapojanakul, S.; Burnett, W.C.;

Bidorn, B. Did the Construction of the

Bhumibol Dam Cause a Dramatic

Reduction in Sediment Supply to the

Chao Phraya River?. Water 2021, 13,

386. https://doi.org/10.3390/

w13030386

Academic Editor: María

Luz Rodríguez-Blanco

Received: 30 November 2020

Accepted: 29 January 2021

Published: 2 February 2021

Publisher's Note: MDPI stays neutral with regard to jurisdictional claims in published maps and institutional affiliations.

Copyright: (c) 2021 by the authors. Licensee MDPI, Basel, Switzerland. This article is an open access article distributed under the terms and conditions of the Creative Commons Attribution (CC BY) license (https:/ / creativecommons.org/licenses/by/ $4.0 /)$.

\begin{abstract}
The Bhumibol Dam on Ping River, Thailand, was constructed in 1964 to provide water for irrigation, hydroelectric power generation, flood mitigation, fisheries, and saltwater intrusion control to the Great Chao Phraya River basin. Many studies, carried out near the basin outlet, have suggested that the dam impounds significant sediment, resulting in shoreline retreat of the Chao Phraya Delta. In this study, the impact of damming on the sediment regime is analyzed through the sediment variation along the Ping River. The results show that the Ping River drains a mountainous region, with sediment mainly transported in suspension in the upper and middle reaches. By contrast, sediment is mostly transported as bedload in the lower basin. Variation of long-term total sediment flux data suggests that, while the Bhumibol Dam does effectively trap sediment, there was only a $5 \%$ reduction in sediment supply to the Chao Phraya River system because of sediment additions downstream.
\end{abstract}

Keywords: riverine sediment processes; sediment load; river survey; human activity; bedload

\section{Introduction}

Rivers are significant sources of freshwater, sediment, and nutrients to the oceans [1-3]. Riverine sediment flux determines the sedimentation rate and evolution of deltas $[4,5]$. Climate change caused by anthropogenic activities can significantly alter river runoff and sediment processes. Deforestation for agriculture, population pressures, water resources development, and dam construction are all factors that induce changes in river sediment loads [6-12]. Significant reduction of sediment load in many rivers has resulted from reservoir damming, such as in the Nile River $[13,14]$, the Yangtze River $[5,15,16]$, and the Yellow River $[17,18]$. Understanding the response of streamflow and sediment load to human activities is necessary for accurate ecological, geomorphological, and environmental studies [5-12,15-18] for better water resource and coastal engineering management [19]. In modern society, rivers are increasingly impacted by human activities such as dam construction, water management, sand mining, and soil conservation [5,20-22]. Many studies have reported the effects of human activities on riverine sediment flux during the past decades [23-25]. However, a systematic assessment of human-induced changes in riverine sediment properties (sediment flux, concentration, grain size, and deposition/erosion) has only been done in certain cases [5].

The Chao Phraya River (CPR) basin, the largest in Thailand, delivers fluvial sediments into the Gulf of Thailand, forming the Chao Phraya Delta (CPD) at a historical progradation 
rate of $1.5 \mathrm{~km}^{3} / \mathrm{y}$ [26]. In 1952, Thailand undertook a 25-year irrigation system project, the Great Chao Phraya Project, which was then the largest water development project in Asia [27]. This project involved the construction of two large multipurpose reservoirs, the Bhumibol Dam on the Ping River (completed in 1964) and the Sirikit Dam on the Nan River (completed in 1972) and also the construction of many other water distribution systems throughout the CPR basin [27]. Hydrological changes and water use in the CPR basin have significantly impacted the sediment regime. During the past 20 years, many studies have evaluated the impact of dam construction on sediment supply to the Chao Phraya Delta. Suspended sediment data records were sourced from a hydrological station (C.2 in Figure 1) operated by the Royal Irrigation Department (RID). Most studies suggested that the construction of the two dams caused a $70-85 \%$ reduction in sediment supplied to the $\mathrm{CPD}$, resulting in severe shoreline recession of the delta during the past three decades [28-32].

Rivers are complex nonlinear dynamic systems [12]. Therefore, assessing the damming impacts on sediment based only on suspended sediment load (SSL) data at Station C.2 may not be sufficient. Station C.2 is located $265 \mathrm{~km}$ downstream of the Bhumibol Dam and $460 \mathrm{~km}$ downstream of the Sirikit Dam. Thus, a more rigorous and systematic approach should be used to measure the sediment properties and evaluate the impact of damming on the sediment regime. The objectives of this study were to: 1) examine sediment characteristics of the Ping River based on systematic river observations; 2) evaluate the temporal variation of sediment loads along the Ping River, and 3) systematically assess the impacts of the Bhumibol Dam on the downstream sediment supply from the Ping River to the CPR system.

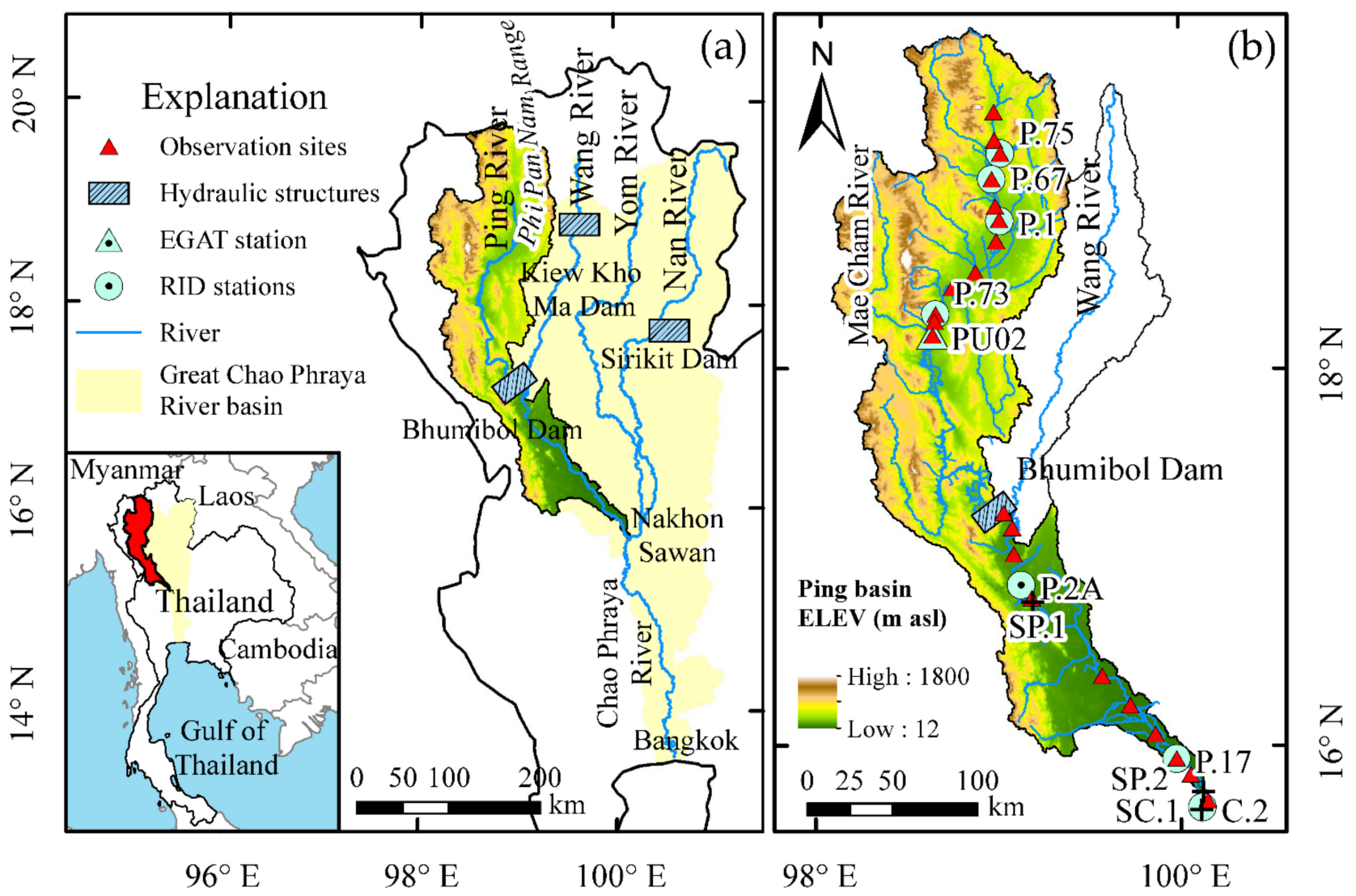

Figure 1. Map of the Chao Phraya River Basin, Thailand: (a) Ping River Basin and location of the Bhumibol Dam, the largest dam in the Chao Phraya River system; (b) locations of observation sites and hydrological stations operated by the Royal Irrigation Department (RID) and the Electricity Generating Authority of Thailand (EGAT). 


\section{Materials and Methods}

\subsection{Study Area}

The Ping River Basin is the largest of the four major river basins that form the Chao Phraya River system. The basin is in Northern Thailand with a watershed of $34,450 \mathrm{~km}^{2}$ (Figure 1). The Ping River originates in the Phi Pan Nam Range (the northmost mountain range of Thailand) and flows southward through major upper north valleys before traversing the lowland areas in the lower north, merging with the Nan River and forming the Chao Phraya River at Nakhon Sawan [33]. The gradient of the Ping River ranges between 1:700 and 1:2700 (Figure 2), with a total mainstream length of $740 \mathrm{~km} \mathrm{[28,34].}$

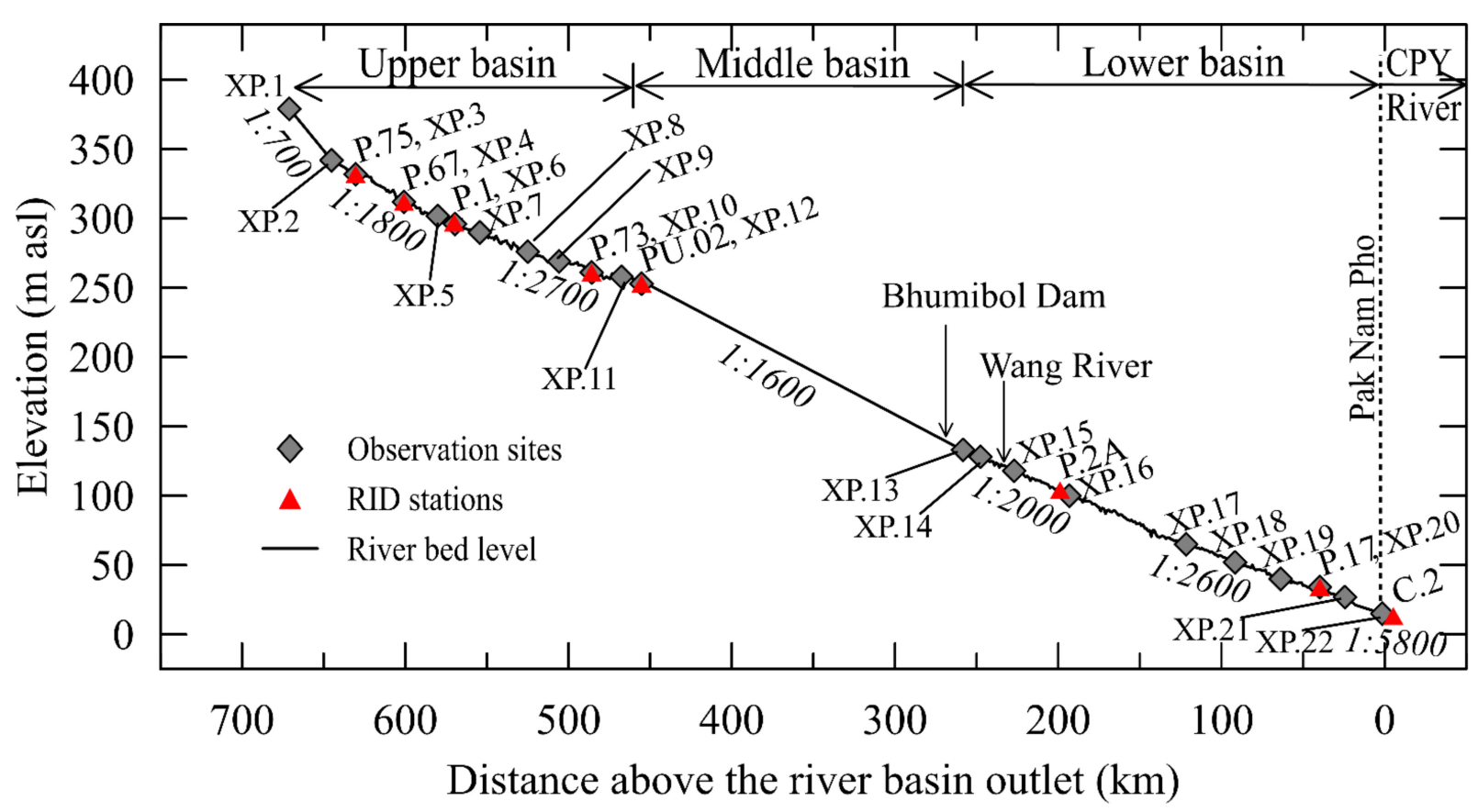

Figure 2. Longitudinal profile of the Ping River showing locations of RID hydrological stations (red triangles) and observation sites (grey diamonds). The zero mark on the $x$-axis represents the confluence of the Ping and Nan Rivers.

Geomorphologically, the Ping River can be divided into upper, middle, and lower basins. The upper basin is mainly characterized by mountainous features [27] with a shallow mainstream channel 40-70 $\mathrm{m}$ wide and less than $5 \mathrm{~m}$ deep. The middle basin consists of valleys and highland areas. The river reach widens to $40-200 \mathrm{~m}$ and deepens to 5-8 $\mathrm{m}$. Lowland areas describe the lower basin characteristics, with the average river gradient significantly decreasing to 1:2500. River width in the lower reach increases to 200-400 $\mathrm{m}$ and the depth decreases to less than $5 \mathrm{~m}$ [35]. Before merging with the Nan River to form the Chao Phraya River, the lower Ping River narrows to approximately $200 \mathrm{~m}$ and deepens to $8 \mathrm{~m}$.

The northeast monsoon impacts the climate of the Ping River Basin from November to mid-March (dry season), with the southwest monsoon from mid-May to September (wet season) [34]. About $90 \%$ of the annual rainfall $(1100 \mathrm{~mm})$ occurs during the wet season [36]. The Ping River Basin has an average annual runoff of $9300 \times 10^{6} \mathrm{~m}^{3} / \mathrm{y}$, accounting for $24 \%$ of the CPR's runoff [36]. The Bhumibol Dam was constructed on the middle reach of the Ping River (Figure 1) and completed in 1964 as a major component of the Great Chao Phraya Project. The dam is operated as a multipurpose dam for irrigation, hydroelectric power generation, flood mitigation, fisheries, and saltwater intrusion control $[37,38]$. With maximum storage of $13,462 \times 10^{6} \mathrm{~m}^{3} / \mathrm{y}$ [39], the dam is the most massive structure in the Chao Phraya River system. 


\subsection{Variability and Trend Analysis of River Discharges and Sediment Loads}

Historical daily data on river discharge $\left(\mathrm{Q}_{\mathrm{W}}\right)$ and suspended sediment data $\left(\mathrm{Q}_{\mathrm{s}}\right)$ from 1921 to 2019 were obtained from the Royal Irrigation Department (RID) and the Electricity Generating Authority of Thailand (EGAT). These data were used to study the variability of river flow and sediment load along the Ping River. Daily streamflow and sediment data for over 20 years from eight hydrological stations (P.1, P.2A, P.17, P.67, P.73, P.75, PU02, and C.2 in Figure 1b) were also used in this study. Stations P.75, P.67, and P.1 are located in the upper Ping River Basin, Stations P.73 and PU02 are in the middle basin and Station P.17 is in the lower basin. Data recorded at Station C.2, located $5 \mathrm{~km}$ downstream from the confluence of the Ping and Nan Rivers, were used to assess the impact of the Bhumibol Dam on sediment supplied to the CPR.

Bedload data are not generally available in Thailand. Measured bedload between 2011 and 2013 at three locations (SP.1, SP.2, and SC.1 in Figure 1b) in the lower Ping River and the CPR reported by Bidorn et al. [34] and Bidorn et al. [40] were used to evaluate the characteristics of bedload in the lower Ping River and the Chao Phraya River. To determine total sediment loading in the Ping River system, daily runoff and suspended sediment load data from the RID were used to develop sediment rating curves for each hydrological station, with hindcasted suspended sediment data estimated from daily streamflow data. Meanwhile, river bedload was calculated using the bed to suspended sediment ratio analyzed from study observations. Total sediment load was obtained as the summation of the bedload and suspended sediment load.

Streamflow and sediment data trends at each station were analyzed using the MannKendall (MK) test as a non-parametric statistical method [41,42]. The MK test has been widely used to identify monotonic trends in environmental climate and hydrological data containing non-normally distributed, censored, and missing data. [15,43-48]. In this study, a statistically significant trend analysis was accepted when the $p$-value was less than 0.1 [49]. The double mass curve (DMC) of the streamflow versus the sediment load has been extensively used to identify hydrological regime changes due to human activities $[5,15,34,44,47-50]$. Here, we use DMC plots of total sediment load data covering pre-and post-dam construction were used to assess the effect of the Bhumibol Dam on sediment loads in the Ping and Chao Phraya Rivers.

\subsection{Measurement of River Discharge and Sediment Data}

Without bedload data, SSL data recorded at the hydrological stations were insufficient to analyze dynamic sediment processes and assess human activities in the Ping River basin. River surveys were carried out twice in 2019 at 22 sites along the Ping River (XP.1XP.22), as shown in Figure 2. Six observation sites, XP.1-XP.6, were located in the upper reach, and six sites, XP.7-XP.12, were located in the middle reach. The remaining 10 sites (XP.13-XP.22) were located along the lower reach of the Ping River. The observation period covered both wet and dry seasons, and observation data included river discharge, river cross-section, suspended sediment concentration, bedload transport rate, and bed material. Streamflow data (discharges and velocities) and cross-sections were measured using an Acoustic Doppler Current Profiling system (ACDP), Sontek River Surveyer M9 (M9), which quickly and accurately collects discharge and cross-sectional areas. Measurement accuracy was $\pm 0.25 \mathrm{~cm} / \mathrm{s}$ and $1 \%$ for flow velocity and water depth, respectively. The resolution was $0.001 \mathrm{~m} / \mathrm{s}$ for velocity measurement and $0.001 \mathrm{~m}$ for depth measurement. At each observation location, the M9 was operated back and forth across the river channel to measure the velocity profile and water depth across the flow area. Then, the river discharge at each river cross-section was automatically calculated.

For suspended sediment concentrations, water samples were collected using depthintegrated sediment samplers. The samples were mainly collected using a US D-49 (HyQuest Solutions Pty Ltd., New South Wales, Australia), while a US DH-48 (HyQuest Solutions Pty Ltd., New South Wales, Australia) was used to obtain samples during wadable flow. To collect the suspended sediment samples at each location, the river was divided into 
5-11 equal-width increments depending on the width. Then, depth-integrated sediment samples were collected at the centroid of each increment. The sampler was lowered to the river bottom and immediately raised to the surface to fill the sampler to about $90 \%$ capacity. The samples were then transported to a laboratory for analyzing sediment concentrations. Water samples were filtered using a pre-weighed GIF filter paper with a pore diameter of $0.45 \mu \mathrm{m}$. The retained sediment on the filter was dried (for $24 \mathrm{~h}$ at $105^{\circ} \mathrm{C}$ ) and weighed. Total suspended sediment concentration (C) was calculated from the dry weight of retained sediment (in grams) divided by the volume $(\mathrm{mL})$ of the sample. By multiplying the suspended sediment concentration by the corresponding discharge $\left(\mathrm{Q}_{\mathrm{w}}\right)$, the SSL $\left(\mathrm{Q}_{\mathrm{s}}\right)$ at each river section was obtained.

Bed-load $\left(\mathrm{Q}_{\mathrm{b}}\right)$, BL, was measured by a standard Helley-Smith (U.S. BL-84) sampler, medium-weight equipment. The sampler consisted of a square nozzle of $0.076 \mathrm{~m}$ intake and a sampling bag made of $25 \mu \mathrm{m}$-mesh polyester, allowing the collection of gravel and sand with a diameter greater than $0.025 \mathrm{~mm}$. The sampler was lowered from the bridge into the riverbed. The bedload sample was taken between 1-3 min at 5-11 verticals across the river channel corresponding to the suspended sediment sampling locations. The samples were oven-dried at $105{ }^{\circ} \mathrm{C}$ and weighed in a soil laboratory. Then, the grain size distribution of each dried sample was determined using the sieve analysis method, a standard test method of soil particle-size analysis (ASTM D422). The gradation was analyzed by allowing the material to pass through a series of sieves of progressively smaller mesh size and weighing the amount of sediment material that is retained on each sieve as a fraction of the whole mass. By dividing the dry mass of sediment catch $(\mathrm{kg})$ by the product of the intake width $(0.076 \mathrm{~m})$ and the sampling period (minute), the bedload transport rate $\left(\mathrm{Q}_{\mathrm{b}}\right)$ at the sampling point was calculated. An average bedload transport rate for each increment was estimated from the product of the wetted perimeter of the increment and the instant bedload transport rate sampling at each increment. The total bedload transport rate across the river was estimated from the summation of the average bedload transport rate over the full river cross-section [51,52].

\section{Results}

\subsection{Historical River Flow and Sediment Loads}

\subsubsection{Historical River Flow along the Ping River}

The annual river flows observed at several stations from 1921 to 2019 are illustrated in Figure 3, with basic statistical parameters analyzed from daily discharge and SSL presented in Table 1. Average streamflow at each station revealed that the river flow increased downstream, varying from $20 \mathrm{~m}^{3} / \mathrm{s}$ (P.75) to about $250 \mathrm{~m}^{3} / \mathrm{s}$ (P.17; $40 \mathrm{~km}$ upstream from the river outlet). Moreover, average river discharge at P.17 accounted for $36 \%$ of the CPR discharge at C.2, located $5 \mathrm{~km}$ downstream from the outlet.

Results from river flow analysis in the upper Ping River Basin (P.75, P.67, and P.1) indicated that the river flow increased downstream. During the last 20 years, the streamflow at $P .75$ and $P .67$ varied between 0 and $855 \mathrm{~m}^{3} / \mathrm{s}$, with no statistically significant increasing or decreasing trends observed in the river flow at these locations ( $p$-values $>0.1$ ). A significant decreasing trend was shown by a century of time-series flow data at P.1. Figure 3 illustrates the variation of annual river flow at P.1 $(p$-value $=0.001)$, which averaged below $1750 \times 10^{6} \mathrm{~m}^{3} / \mathrm{y}$. We observed higher river flows occurred at P.1 between 1970 and 1975 . Since 1982, the annual runoff was generally lower than the river flow before the 1970s; however, a high rate of streamflow was observed during severe flood events in Thailand, such as 1995, 2005, and 2011. In the middle Ping River Basin, most of the river reach was inundated by the Bhumibol Reservoir. Two decades of streamflow data at P.73 and PU02, situated upstream of the Bhumibol Reservoir, showed that average streamflow in the middle reach was 1.5 to 6.3 times greater than that in the upper reach. River flow draining into the Bhumibol Reservoir ranged from $\sim 0$ to $2427 \mathrm{~m}^{3} / \mathrm{s}$. A statistically decreasing trend in river flow was found at both Stations P.73 $(p$-value $=0.071)$ and PU02 $(p$-value $=0.041)$. We consider downstream of the Bhumibol Dam as the lower Ping River Basin. Based on 
the time series of river flow at Stations P.2A and P.17 over the past 65 years (covering the pre-dam construction period), results suggested that streamflow slightly increased toward downstream, with river discharge varying from $\sim 0$ to $4760 \mathrm{~m}^{3} / \mathrm{s}$. Similar to Station P.1, river flow in the lower reach appeared to have high fluctuation, especially after 1995 but with no significant increasing or decreasing trend. The Ping River drains to the Chao Phraya River at Pak Nam Pho district (5 km upstream of C.2) (Figure 2). Historical data from 1956 to 2019 revealed that streamflow at C.2 fluctuated between 15 and $5450 \mathrm{~m}^{3} / \mathrm{s}$, with an average rate of $711 \mathrm{~m}^{3} / \mathrm{s}$.

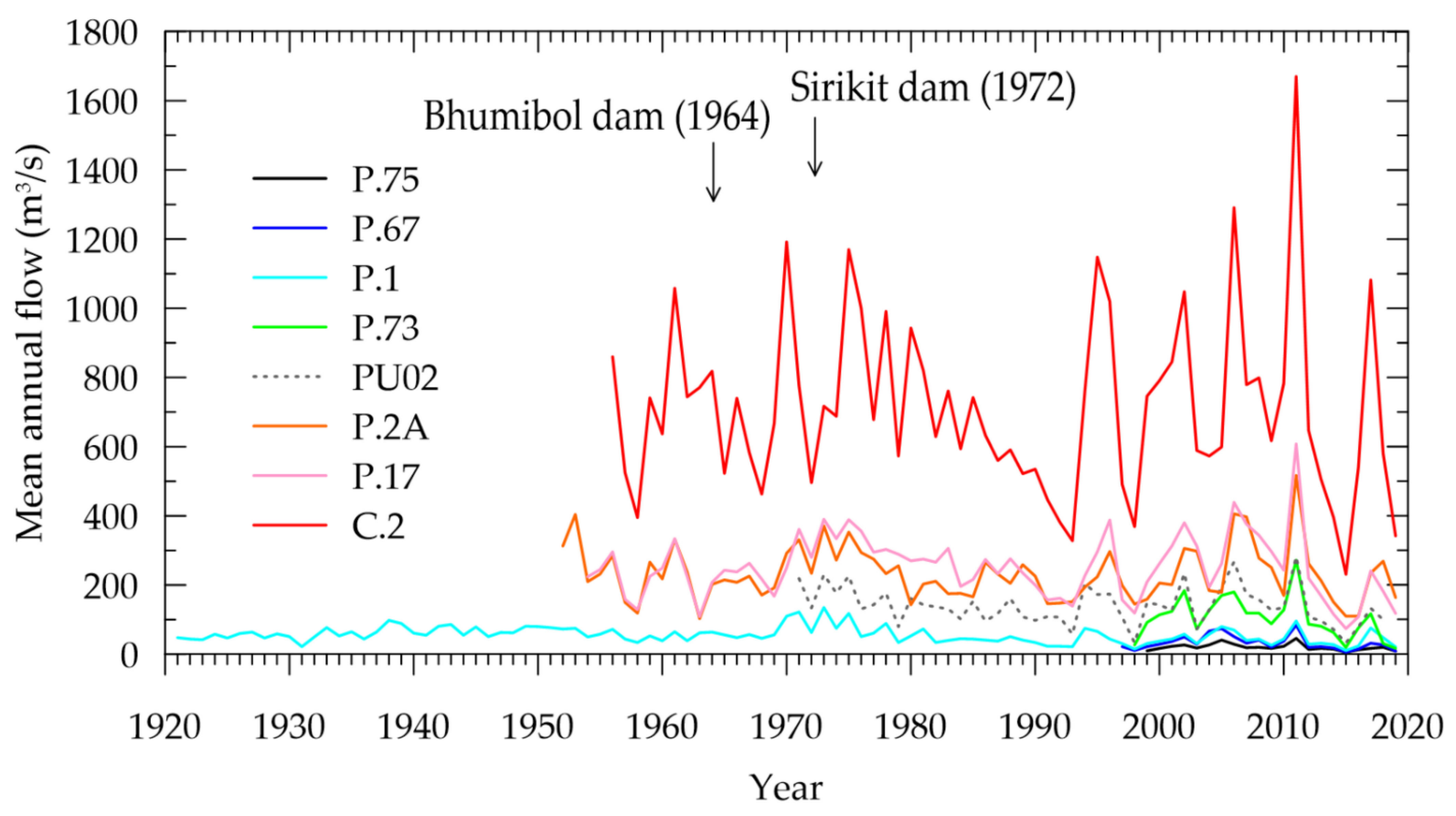

Figure 3. Time series of annual runoff at hydrological stations along the Ping River between 1921 and 2019.

Table 1. Summary of available data and statistics of daily streamflow and suspended sediment at seven RID and EGAT hydrological stations on the Ping River and Station C.2 on the Chao Phraya River (Significance accepted at $p$-value $<0.10$ ).

\begin{tabular}{|c|c|c|c|c|c|c|c|c|c|}
\hline Sta. & $\begin{array}{l}{ }^{1} \text { Dist. } \\
\text { (km) }\end{array}$ & $\begin{array}{c}\text { Drainage } \\
\left(\mathrm{km}^{2}\right)\end{array}$ & Data & Period & Max. & Ave. & Min. & ${ }^{4} p$-Value & ${ }^{5}$ Trend \\
\hline \multirow[t]{2}{*}{ P.75 } & +667 & 3088 & ${ }^{2} Q_{w}\left(m^{3} / s\right)$ & 1999-2019 & 336 & 20 & $\sim 0$ & 0.142 & Decreasing \\
\hline & & & ${ }^{3} \mathrm{Q}_{\mathrm{s}}(\mathrm{t} / \mathrm{d})$ & 2001-2019 & 16,457 & 249 & $\sim 0$ & 0.106 & Decreasing \\
\hline \multirow[t]{2}{*}{ P.67 } & +603 & 5323 & $\mathrm{Q}_{\mathrm{w}}\left(\mathrm{m}^{3} / \mathrm{s}\right)$ & 1997-2019 & 853 & 33 & $\sim 0$ & 0.295 & Decreasing \\
\hline & & & $\mathrm{Q}_{\mathrm{s}}(\mathrm{t} / \mathrm{d})$ & 2007-2019 & 40,461 & 604 & $\sim 0$ & 0.204 & Decreasing \\
\hline \multirow[t]{2}{*}{ P.1 } & +570 & 6355 & $\mathrm{Q}_{\mathrm{w}}\left(\mathrm{m}^{3} / \mathrm{s}\right)$ & 1921-2019 & 1090 & 55 & $\sim 0$ & 0.001 & Decreasing \\
\hline & & & $\mathrm{Q}_{\mathrm{s}}(\mathrm{t} / \mathrm{d})$ & 1993-2019 & 46,329 & 712 & $\sim 0$ & 0.091 & Decreasing \\
\hline \multirow[t]{2}{*}{ P.73 } & +472 & 14,814 & $\mathrm{Q}_{\mathrm{w}}\left(\mathrm{m}^{3} / \mathrm{s}\right)$ & 1998-2019 & 1777 & 131 & $\sim 0$ & 0.071 & Decreasing \\
\hline & & & $\mathrm{Q}_{\mathrm{s}}(\mathrm{t} / \mathrm{d})$ & 2001-2019 & 29,448 & 1099 & $\sim 0$ & 0.109 & Decreasing \\
\hline \multirow[t]{2}{*}{ PU02 } & +455 & 18,932 & $\mathrm{Q}_{\mathrm{w}}\left(\mathrm{m}^{3} / \mathrm{s}\right)$ & 1971-2018 & 2427 & 139 & $\sim 0$ & 0.041 & Decreasing \\
\hline & & & $\mathrm{Q}_{\mathrm{s}}(\mathrm{t} / \mathrm{d})$ & 2001-2018 & 315,865 & 4453 & $\sim 0$ & 0.165 & Decreasing \\
\hline \multirow[t]{2}{*}{ P.2A } & +200 & 38,862 & $\mathrm{Q}_{\mathrm{w}}\left(\mathrm{m}^{3} / \mathrm{d}\right)$ & 1954-2019 & 4760 & 245 & $\sim 0$ & 0.230 & Decreasing \\
\hline & & & $\mathrm{Q}_{\mathrm{s}}(\mathrm{t} / \mathrm{d})$ & 1989-2000 & 25,347 & 2271 & 16 & 0.862 & Decreasing \\
\hline \multirow[t]{2}{*}{ P.17 } & +40 & 45,297 & $\mathrm{Q}_{\mathrm{w}}\left(\mathrm{m}^{3} / \mathrm{s}\right)$ & 1954-2019 & 2351 & 252 & $\sim 0$ & 0.507 & Decreasing \\
\hline & & & $\mathrm{Q}_{\mathrm{s}}(\mathrm{t} / \mathrm{d})$ & 2001-2019 & 32,902 & 1753 & 9 & 0.127 & Decreasing \\
\hline \multirow[t]{2}{*}{ C. 2} & -5 & 109,973 & $\mathrm{Q}_{\mathrm{w}}\left(\mathrm{m}^{3} / \mathrm{s}\right)$ & 1956-2019 & 5451 & 711 & 15 & 0.316 & Decreasing \\
\hline & & & $\mathrm{Q}_{\mathrm{s}}(\mathrm{t} / \mathrm{d})$ & 1965-2019 & 493,805 & 13,705 & 236 & 0.001 & Decreasing \\
\hline
\end{tabular}

${ }^{1}$ Distance from the Ping River outlet: + sign is the distance from the outlet toward upstream, - sign is the distance from the outlet toward downstream. ${ }^{2} \mathrm{Q}_{\mathrm{w}}$ is river discharge $\left(\mathrm{m}^{3} / \mathrm{s}\right) .{ }^{3} \mathrm{Q}_{\mathrm{s}}$ is suspended sediment load $(\mathrm{t} / \mathrm{d}) .{ }^{4} p$-value and ${ }^{5}$ Trend refer to Mann-Kendal test; statistically significant trend is marked as the bold text. 


\subsubsection{Historical Suspended Sediment Loads along the Ping River}

Figure 4 illustrates the time series of annual SSL observed at several hydrological stations from 1965 to 2019. Analysis of historical SSL data available at P.75, P.67, and P.1 revealed that suspended sediment fluxes in the upper Ping River Basin increased downstream. The SSL fluctuated between $\sim 0$ and $46,328 \mathrm{t} / \mathrm{d}$ with an average of 249, 604, and $712 \mathrm{t} / \mathrm{d}$ at P.75, P.67, and P.1, respectively. A maximum SSL of 46,330 t/d occurred at P.1 in September 2011 due to the great flood triggered by the tropical storm "Haitang". With 26 years of long-term SSL data, station P.1 showed a significantly decreasing trend ( $p$-value $=0.091)$ for the upper basin. In the middle Ping River Basin, the average SSL at the uppermost section of the middle reach (P.73) was $1100 \mathrm{t} / \mathrm{d}$, and slightly greater than that in the upper basin. However, SSL at PU02 (operated by the EGAT) increased obviously compared with P.73, even though PU02 was $20 \mathrm{~km}$ downstream of P.73. Average SSL at PU02 $(\sim 4450 \mathrm{t} / \mathrm{d})$ was four times greater than at P.73. Results from the MK test showed neither increasing nor decreasing trends in SSL ( $p$-values $>0.1$ ) in the middle basin (Table 1).

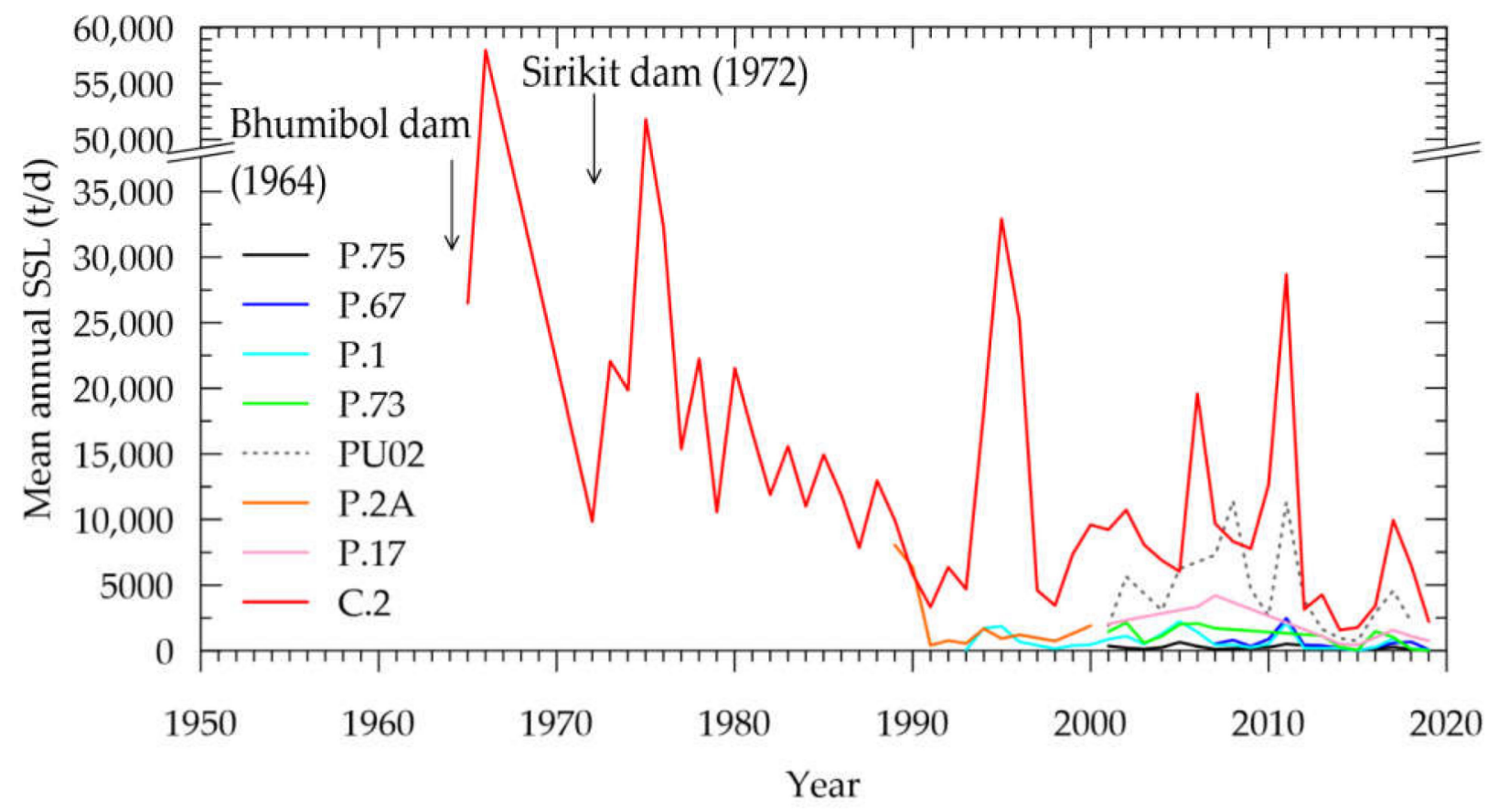

Figure 4. Time series data of annual suspended sediment load at RID hydrological stations along the Ping River between 1965 and 2019.

In the lower Ping River Basin, daily SSL at P.2A and P.17 varied from 9 to 33,000 t/d. Average SSL at P.2A (60 km downstream of Bhumibol Dam) was $2270 \mathrm{t} / \mathrm{d}$ (roughly $50 \%$ lower than at PU02) but was double the SSL measured at P.73. However, the SSL likely decreased near the river outlet (P.17) with an average of $1753 \mathrm{t} / \mathrm{d}$. No statistically significant trend was found in the SSL data of the lower basin ( $p$-values $>0.1$ ). For sediment data at C.2 from 1965 to 2019, SSL ranged from 236 to 494,000 t/d. The MK analysis result indicated that suspended sediment load had a significantly decreasing trend over the past six decades $(p$-value $=0.001)$. Comparing average suspended sediment load between P.17 and C.2 revealed that the average SSL observed at P.17 accounted for 13\% of the SSL at C.2 $(13,700 \mathrm{t} / \mathrm{d})$.

\subsection{River Flow and Sediment Characteristics along the Ping River}

Streamflow and sediment data measured at 22 locations (XP.1-XP.22 in Figure 2) during both dry and wet seasons are shown in Table 2, while the variation of streamflow, 
suspended sediment load, bedload, and bed material along the Ping River are illustrated in Figure 5. Observed river flow and sediment characteristics along the upper reach (XP.1X.P.6), middle reach (XP.7-XP.12), and lower reach (XP.13-XP.22) of the Ping River are summarized below.

Table 2. Observed streamflow and sediment data along the Ping River during 2019.

\begin{tabular}{|c|c|c|c|c|c|c|c|c|c|c|}
\hline Site & $\begin{array}{l}\text { Dist. } \\
(\mathbf{k m})\end{array}$ & $\begin{array}{c}{ }^{1} A \\
\left(m^{2}\right)\end{array}$ & $\begin{array}{c}{ }^{2} \mathrm{~V} \\
(\mathrm{~m} / \mathrm{s})\end{array}$ & $\begin{array}{l}{ }^{3} \mathrm{Q}_{\mathrm{w}} \\
\left(\mathrm{m}^{3} / \mathrm{s}\right)\end{array}$ & $\begin{array}{l}{ }^{4} Q_{s} \\
(t / d)\end{array}$ & $\begin{array}{l}{ }^{5} Q_{b} \\
(t / d)\end{array}$ & $\begin{array}{l}{ }^{6} Q_{t} \\
(t / d)\end{array}$ & $\begin{array}{c}\mathrm{Q}_{\mathrm{b}} / \mathrm{Q}_{\mathrm{s}} \\
(\mathrm{t} / \mathrm{d})\end{array}$ & $\mathrm{Q}_{\mathrm{b}} / \mathrm{Q}_{\mathrm{t}}$ & $\begin{array}{c}\mathrm{d}_{50} \\
(\mathrm{~mm})\end{array}$ \\
\hline \multicolumn{11}{|c|}{ Dry season } \\
\hline XP.1 & 681.1 & 11.2 & 0.161 & 1.8 & 0.5 & 0.01 & 0.49 & 0.02 & 0.02 & 1.78 \\
\hline XP.2 & 653.0 & 12.1 & 0.247 & 3.0 & 1.3 & 0 & 1.27 & 0 & 0 & 1.90 \\
\hline XP.3 & 636.5 & 12.8 & 0.642 & 8.2 & 2.8 & 0 & 2.76 & 0 & 0 & 2.75 \\
\hline XP.4 & 602.7 & 64.6 & 0.183 & 11.8 & 20.9 & 0 & 20.91 & 0 & 0 & 5.46 \\
\hline XP.5 & 581.8 & 23.0 & 0.547 & 12.6 & 40.4 & 1.68 & 42.08 & 0.04 & 0.04 & 1.99 \\
\hline XP.6 & 571.0 & 114.8 & 0.111 & 12.8 & 24.1 & 0.02 & 24.13 & 0.001 & 0.001 & - \\
\hline XP.7 & 555.6 & 58.4 & 0.180 & 10.5 & 13.0 & 0.30 & 13.27 & 0.02 & 0.02 & 1.60 \\
\hline XP.8 & 525.6 & 144.9 & 0.091 & 13.2 & 10.0 & 0 & 10.03 & 0 & 0 & 1.33 \\
\hline XP.9 & 507.2 & 137.5 & 0.030 & 4.1 & 2.7 & 0 & 2.73 & 0 & 0 & - \\
\hline XP.10 & 472.7 & 28.5 & 0.039 & 1.1 & 1.3 & 0 & 1.32 & 0 & 0 & 1.63 \\
\hline XP.11 & 467.2 & 151.8 & 0.009 & 1.3 & 1.2 & 0 & 1.15 & 0 & 0 & 0.79 \\
\hline XP.12 & 455.3 & 44.7 & 0.101 & 4.5 & 12.2 & 0 & 12.21 & 0 & 0 & 1.53 \\
\hline XP.13 & 253.3 & 246.2 & 1.073 & 264.2 & 66.2 & 18.62 & 84.82 & 0.28 & 0.22 & 1.13 \\
\hline XP.14 & 243.0 & 179.5 & 0.260 & 46.7 & 39.1 & 4.55 & 43.69 & 0.12 & 0.10 & 0.85 \\
\hline XP.15 & 222.5 & 249.0 & 0.354 & 87.5 & 33.3 & 358.01 & 391.27 & 10.76 & 0.92 & 0.85 \\
\hline XP.16 & 188.9 & 233.3 & 0.633 & 147.6 & 271.6 & 3118.28 & 2389.92 & 11.48 & 0.92 & 0.82 \\
\hline XP.17 & 119.5 & 278.8 & 0.878 & 244.2 & 422.0 & 411.43 & 863.41 & 1.046 & 0.51 & 1.10 \\
\hline XP.18 & 90.0 & 235.5 & 0.583 & 137.4 & 176.9 & 1014.50 & 1191.38 & 5.74 & 0.85 & 1.58 \\
\hline XP.19 & 62.7 & 356.9 & 0.411 & 146.6 & 367.3 & 39.40 & 406.71 & 0.11 & 0.10 & 2.82 \\
\hline XP.20 & 39.6 & 354.3 & 0.454 & 160.8 & 516.8 & 10.53 & 527.35 & 0.02 & 0.02 & 1.03 \\
\hline XP.21 & 24.1 & 331.9 & 0.453 & 150.5 & 420.0 & 146.39 & 566.39 & 0.35 & 0.26 & 1.09 \\
\hline XP.22 & 1.5 & 220.7 & 0.541 & 119.5 & 350.0 & 46.86 & 396.88 & 0.13 & 0.12 & 0.57 \\
\hline \multicolumn{11}{|c|}{ Wet season } \\
\hline XP.1 & 681.1 & 19.9 & 0.23 & 4.6 & 24.6 & 0 & 24.6 & 0 & 0 & 2.50 \\
\hline XP.2 & 653.0 & 18.6 & 0.40 & 7.5 & 74.3 & 0.04 & 74.4 & 0.001 & 0.001 & 4.01 \\
\hline XP.3 & 636.5 & 8.0 & 0.61 & 4.9 & 20.6 & 0.76 & 21.3 & 0.04 & 0.04 & 10.24 \\
\hline XP.4 & 602.7 & 59.4 & 0.14 & 8.1 & 53.3 & 0 & 53.3 & 0 & 0 & 2.32 \\
\hline XP.5 & 581.8 & 24.8 & 0.51 & 12.7 & 63.9 & 1.79 & 65.6 & 0.03 & 0.03 & 1.44 \\
\hline XР.6 & 571.0 & 118.2 & 0.10 & 11.6 & 29.5 & 0 & 29.5 & 0 & 0 & 0.54 \\
\hline XP.7 & 555.6 & 51.8 & 0.10 & 5.2 & 0.6 & 0 & 0.6 & 0 & 0 & 2.34 \\
\hline XP.8 & 525.6 & 49.8 & 0.02 & 1.0 & 0.3 & 0 & 0.3 & 0 & 0 & 1.34 \\
\hline XP.9 & 507.2 & 138.7 & 0.001 & 0.2 & 0.2 & 0 & 0.2 & 0 & 0 & 0.65 \\
\hline XP.10 & 472.7 & 36.7 & 0.008 & 0.3 & 0.6 & 0 & 0.6 & 0 & 0 & 0.62 \\
\hline XP.11 & 467.2 & 126.9 & 0.006 & 0.8 & 0.6 & 0 & 0.6 & 0 & 0 & 1.61 \\
\hline XP.12 & 455.3 & 80.9 & 0.25 & 20.3 & 2757.5 & 7.32 & 2764.8 & 0.003 & 0.003 & 0.49 \\
\hline XP.13 & 253.3 & 294.2 & 1.34 & 395.4 & 95.7 & 5.51 & 101.2 & 0.06 & 0.05 & 1.16 \\
\hline XP.14 & 243.0 & 149.9 & 0.24 & 35.7 & 5.2 & 2.64 & 7.9 & 0.50 & 0.34 & 0.78 \\
\hline XP.15 & 222.5 & 278.3 & 0.47 & 129.9 & 19.1 & 1017.44 & 1036.5 & 53.33 & 0.98 & 1.35 \\
\hline XP.16 & 188.9 & 391.8 & 0.67 & 268.4 & 213.4 & 3843.66 & 4057.0 & 18.02 & 0.95 & 0.85 \\
\hline XP.17 & 119.5 & 275.9 & 0.81 & 222.4 & 155.6 & 574.74 & 730.4 & 3.69 & 0.79 & 1.71 \\
\hline XP.18 & 90.0 & 298.3 & 0.64 & 193.0 & 160.1 & 1656.93 & 1817.0 & 10.35 & 0.91 & 0.72 \\
\hline XP.19 & 62.7 & 343.8 & 0.47 & 160.8 & 157.0 & 182.06 & 339.1 & 1.16 & 0.54 & 0.81 \\
\hline XP.20 & 39.6 & 342.3 & 0.49 & 169.1 & 192.7 & 43.94 & 236.8 & 0.23 & 0.19 & 0.81 \\
\hline XP.21 & 24.1 & 329.7 & 0.47 & 153.5 & 157.8 & 225.32 & 383.1 & 1.43 & 0.59 & 0.67 \\
\hline XP.22 & 1.5 & 218.9 & 0.70 & 153.2 & 221.1 & 253.87 & 479.9 & 1.15 & 0.54 & 0.38 \\
\hline
\end{tabular}

${ }^{1} \mathrm{~A}$ is flow area; ${ }^{2} \mathrm{~V}$ is flow velocity; ${ }^{3} \mathrm{Q}_{\mathrm{W}}$ is river discharge; ${ }^{4} \mathrm{Q}_{\mathrm{s}}$ is suspended sediment load; ${ }^{5} \mathrm{Q}_{\mathrm{b}}$ is bedload; ${ }^{6} \mathrm{Q}_{\mathrm{t}}$ is total sediment load. $\mathrm{d}_{50}$ is median grain size of the sediment. 


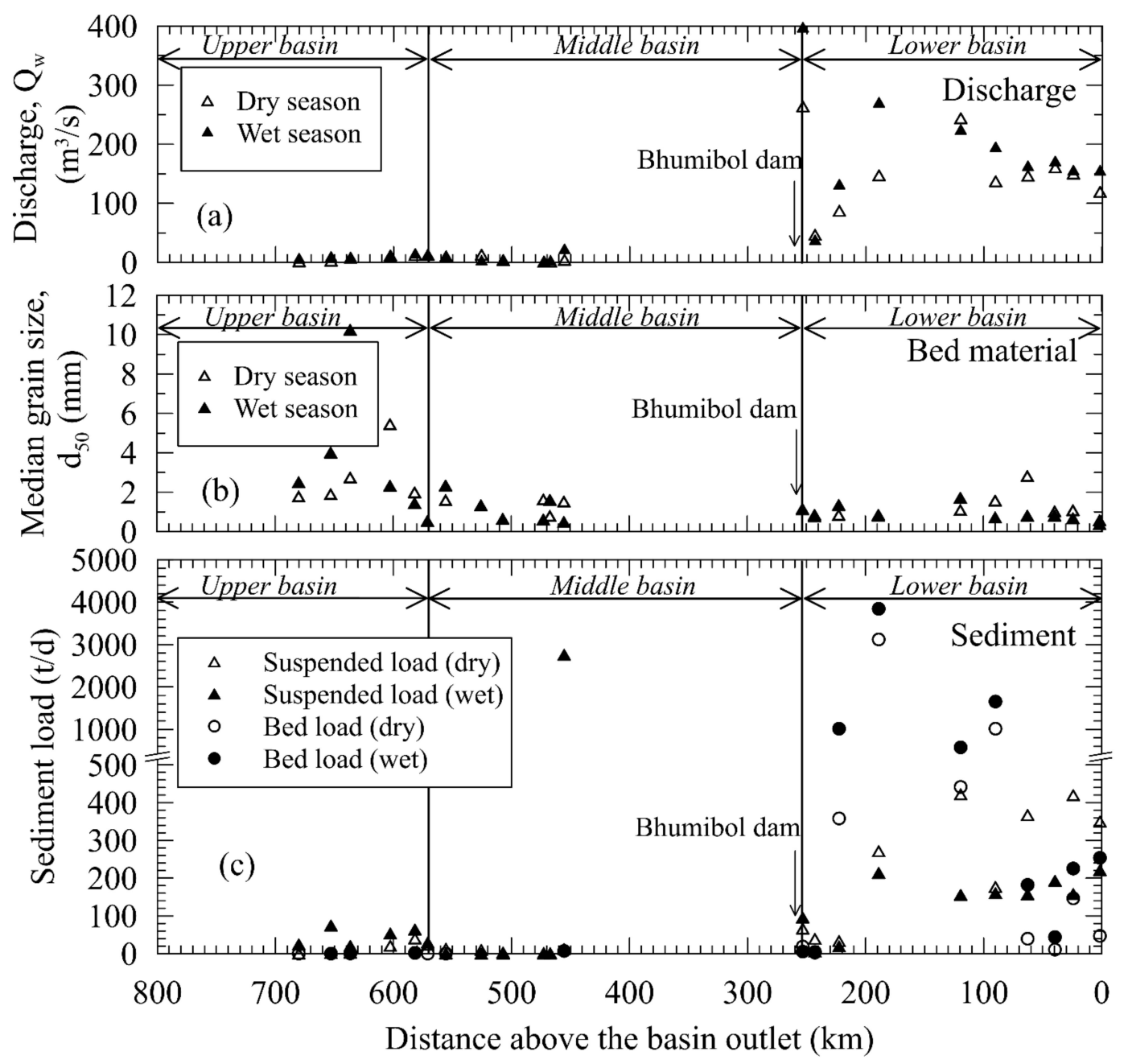

Figure 5. Observations along the Ping River during 2019: (a) river discharge; (b) median size bed material ( $\left.d_{50}\right)$; (c) suspended sediment load and bedload.

During the dry season of 2019, streamflow in the upper and middle Ping River Basin ranged $1.8-12.8 \mathrm{~m}^{3} / \mathrm{s}$ and $1.1-13.2 \mathrm{~m}^{3} / \mathrm{s}$, while streamflow noticeably increased at $46.7-264.2 \mathrm{~m}^{3} / \mathrm{s}$ in the lower basin (Figure $5 \mathrm{a}$ ). The upper reaches of the river are characterized by very coarse sand and pebbles with $d_{50}$ of $1.78-5.46 \mathrm{~mm}$. Bed materials found in the middle and lower reaches were mainly composed of coarse sand and very coarse sand with $d_{50}$ ranging between 0.8 and $2.0 \mathrm{~mm}$ (Figure $5 \mathrm{~b}$ ). The SSL observed in the upper basin varied between 0.5 and $24.1 \mathrm{t} / \mathrm{d}$ and increased toward downstream, whereas the middle basin had lower SSL (1.2-13.0 t/d). However, the SSL increased apparently to $33-520 \mathrm{t} / \mathrm{d}$ in the lower basin. Bedload transported in the upper reach was very low (less than $0.1 \mathrm{t} / \mathrm{d}$, except at XP.5 $(1.7 \mathrm{t} / \mathrm{d}))$. Similarly, no bedload transport was found in the middle reach. However, in the lower reach, bedload dramatically increased at XP.15-18 (Figure 2), ranging at 360-3120 $\mathrm{t} / \mathrm{d}$. These results indicated that the bed to suspended sediment load ratio varied as $0-0.04,0-0.02$, and $0.02-11.5$ in the upper, middle, and lower Ping River reaches, respectively during the dry season.

River survey results during the wet season in 2019 suggested that the streamflow in the upper basin fluctuated at $4.6-12.7 \mathrm{~m}^{3} / \mathrm{s}$, and river flow tended to increase toward downstream. River flow in the middle reach significantly dropped to almost zero before entering the reservoir, except at XP.12 downstream of the Mae Chaem River confluence near PU02 (Figure 2). Water from the Mae Chaem River drains to the Ping River and streamflow observed at XP.12 increased to $20 \mathrm{~m}^{3} / \mathrm{s}$. River discharge rose again in the lower reach because of the water released from the Bhumibol Dam. Streamflow along the lower 
reach ranged at $36-395 \mathrm{~m}^{3} / \mathrm{s}$. Unlike in the dry season, the flow rate in the lower basin decreased downriver. Bed material along the river during the wet season was similar in type to the dry season. For SSL (Figure 5c), the upper basin ranged between 21 and $74 \mathrm{t} / \mathrm{d}$, which was higher than in the dry season. Most of the middle reach had low SSL, except at XP.12 where the highest SSL was observed. However, SSL in the lower reach of the Ping River (5.2-213 t/d) was lower than during the dry season. As in the dry season, BL was rarely observed in most of the upper and middle basins. By contrast, bedload in the lower basin was significantly high, ranging $3-3845 \mathrm{t} / \mathrm{d}$. During the wet season, the bedload to suspended sediment load ratios were $0-0.03$ for the upper and middle reaches but $0.06-50$ for the lower reach.

\subsection{Variability of Sediment Loads along the Ping River}

Total sediment load represents the summation of SSL and BL. The total sediment load at each hydrological station was estimated to evaluate the variability of sediment load along the Ping River and C.2, while Equations (a)-(e), (g) and (h1,h2) obtained from Figure S1 were used to estimate missing SSL data at Stations P.75, P.67, P.1, P.73, PU02, P.17, and C.2 (pre-and post-construction of the two large dams), respectively. Since bedload transport rates typically differ from river to river and even along the same river with high variation, missing bedload data may cause significant uncertainty in the total sediment load of a river. This would be especially true when total sediment data are used to assess how human activities affect fluvial sediment loads. In this study, bedload to suspended sediment ratios at XP.3, XP.4, XP.6, XP.10, and XP.20 were used to estimate daily BL at each station along the Ping River. BL at C.2 was calculated using a bedload to suspended sediment load ratio of 0.03 [34]. The river flow at P.2A has been measured since 1954 but the suspended sediment was only observed from 1989 to 2000 . The suspended sediment load at P.2A had a low correlation to river discharge; therefore, the sediment rating curve at P.2A could not be used to estimate the missing data, and streamflow and suspended sediment data at P.2A were excluded from the analysis of sediment. The summation of the daily total sediment load between 1 April and 31 March of the consecutive year (Thailand's water year) represents the annual total sediment load. Time series of yearly total sediment load in the upper, middle, and lower reaches of the Ping River Basin from 1921 to 2019 are illustrated in Figure S2, and results from basic statistics and trend analyses of annual total sediment load data are summarized in Table 3. In order to evaluate the variation of the river flow and sediment load along the Ping River, the river flow and total sediment load within the same period (1999-2019) at all stations along the river were averaged and plotted as shown in Figure 6. Results in Figure 6 revealed that streamflow apparently increased downstream, while the total sediment load increased between the upper, middle, and lower basins, except at PU02, where the SSL was extremely high.

Table 3. Summary of statistics of estimated total sediment load $\left(\mathrm{Q}_{t}\right)$ at seven RID and EGAT hydrological stations on the Ping River and Station C.2 on the Chao Phraya River (Significance accepted at $p$-value $<0.10$ ).

\begin{tabular}{|c|c|c|c|c|c|c|c|c|}
\hline \multirow{2}{*}{ Sta. } & \multirow{2}{*}{$\begin{array}{l}{ }^{1} \text { Dist. } \\
\text { (km) }\end{array}$} & \multirow{2}{*}{$\begin{array}{c}\text { Drainage } \\
\left(\mathrm{km}^{3}\right)\end{array}$} & \multirow{2}{*}{ Period } & \multicolumn{3}{|c|}{$Q t\left(\times 10^{6} t / y\right)$} & \multirow{2}{*}{${ }^{2} p$-Value } & \multirow{2}{*}{${ }^{3}$ Trend } \\
\hline & & & & Max. & Ave. & Min. & & \\
\hline P.75 & +667 & 3088 & 1999-2019 & 0.25 & 0.09 & 0.01 & 0.432 & Decreasing \\
\hline P.67 & +603 & 5323 & 1997-2019 & 0.91 & 0.27 & 0.01 & 0.566 & Decreasing \\
\hline P.1 & +570 & 6355 & 1921-2019 & 1.237 & 0.33 & 0.01 & 0.003 & Decreasing \\
\hline P.73 & +472 & 14,814 & 1998-2019 & 1.31 & 0.42 & 0.01 & 0.241 & Decreasing \\
\hline PU02 & +455 & 18,932 & 1971-2018 & 4.18 & 1.57 & 0.24 & 0.181 & Decreasing \\
\hline P.2A & +200 & 38,862 & 1991-2000 & 9.83 & 5.34 & 2.03 & 0.109 & Decreasing \\
\hline P.17 & +40 & 45,297 & 1954-2019 & 2.66 & 0.82 & 0.18 & 0.128 & Decreasing \\
\hline C.2 & -5 & 109,973 & 1956-2019 & 21.81 & 4.83 & 0.60 & 0.003 & Decreasing \\
\hline
\end{tabular}

${ }^{1}$ Distance from the Ping River outlet: + sign is the distance from the outlet toward upstream, - sign is the distance from the outlet toward downstream; ${ }^{2} p$-value and ${ }^{3}$ Trend refer to Mann-Kendall test and the significant trend is marked as the bold. 


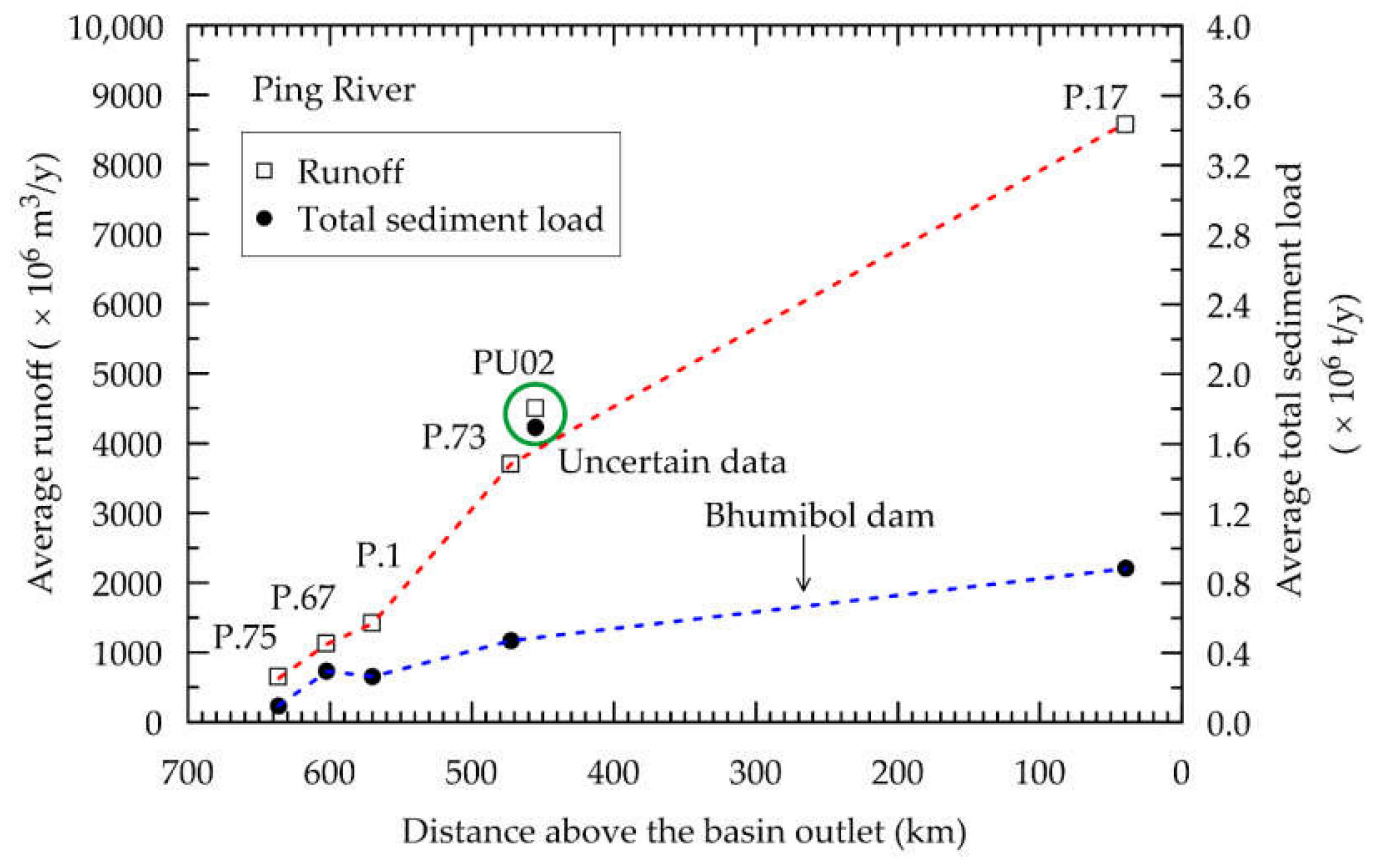

Figure 6. Plots of average annual river runoff and annual total sediment load along the Ping River and C.2 between 1999 and 2019.

\subsection{Effect of the Bhumibol Dam on Sediment Loads in the Ping River}

A double mass curve (DMC) of cumulative annual river runoff and cumulative total sediment load can be used to evaluate the effects of human activities on sediment loads in a river. Construction of the Bhumibol Dam was completed in 1964. Historical river flow and total sediment load data covering pre- and post-dam construction periods were used to assess the impact of the Bhumibol Dam on sediment supply to the Chao Phraya River system. The DMC of Station P.1 (Figure 7a) revealed no obvious change in streamflow and sediment regimes in the upper Ping River Basin from 1950 to 1970. However, the plots showed a temporary increase in total sediment load between 1970 and 1980 as a result of high water, and a substantial reduction of sediment load was also shown after 2005 and 2011. Regarding the DMC of P.17 (Figure 7b), no abrupt change in DMC slope was observed after Bhumibol Dam completion. A shift in the graph was seen in 1995 and 2011 when severe flooding occurred. Figure 7c presents the DMC of C.2. Considerably change in DMC slope occurred immediately after Bhumibol Dam construction. The plot also shows a long-term increase in total sediment load at C.2 instead of a reduction in sediment due to dam impoundment. Similar to P.17, the shift of the graph followed the flood events in 1995 and 2011. Comparison of the total sediment loads between pre- and post-dam construction at P.1 and P.17 revealed that the average daily total sediment load during pre-construction and post-construction of the Bhumibol Dam at P.1 was about $920 \pm 100 \mathrm{t} / \mathrm{d}$ and $880 \pm 100 \mathrm{t} / \mathrm{d}$, respectively. The average daily total sediment load in the lower Ping basin (P.17) before dam construction was approximately $2240 \pm 250 \mathrm{t} / \mathrm{d}$ and after dam construction $2160 \pm 240 \mathrm{t} / \mathrm{d}$. Therefore, the Bhumibol Dam caused sediment reduction at less than $5 \%$ relative to the pre-dam period. 

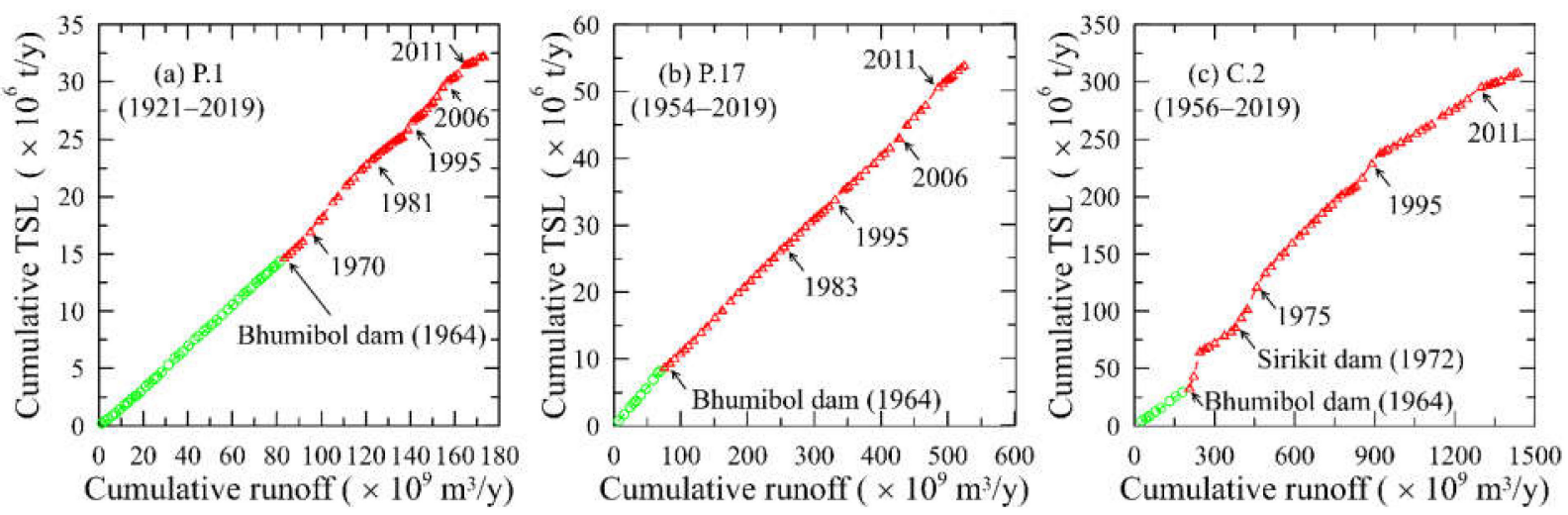

Figure 7. Cumulative annual runoff and total sediment load of the Ping River: (a) P.1; (b) P.17; (c) C.2.; the green and red points represent the data during the pre- and post-construction of the Bhumibol Dam, respectively.

\section{Discussion}

\subsection{Sediment Characteristics}

Based on the geographical features of the basin and a river gradient of 1:700 to 1:2700, the Ping River is characterized as a mountainous river. Results from this study indicate that the SSL in the river is relatively correlated with river flow. With a smaller river cross-section, SSL measurements in the upper and middle basins were relatively low compared to the lower basin. In the middle reach, an obviously higher SSL was observed at Station PU02, while corresponding SSL data measured at P.73 (20 km upstream of PU02) were minimal. This result agrees with the observed SSL data in 2019 that the SSL measured at XP.11 (near P.73) was much lower than XP.12 (near PU02). However, the exceptionally high SSL at XP.12 was only observed during the wet season. Based on field examination, the high SSL at XP.12 was likely caused by the SSL supplied from the Mae Chaem River, which joins the Ping River $1 \mathrm{~km}$ upstream of Stations XP.12 and PU02. Observations also suggested that the Mae Chaem River may convey high SSL and BL to the Ping River resulting in a large sand bar formed at the confluence.

At the Mae Chaem confluence, sand mining extracts sand from the river. These mining activities produce particulate material, and high SSL in samples collected at PU02 is the result. Since sand mining is one of the potential causes of increasing sediment transport in the river [32], the effects of sand mining possibly contribute considerable uncertainty to the SSL data at PU02. In the lower basin, the river reach near the dam had the lowest SSL because water released from the dam during normal operating conditions is typically clear (XP.13-XP.14) (Figure 5c; examples are shown in Figure S3). However, an increase in SSL was found about $40 \mathrm{~km}$ downstream from the dam (XP.15) likely due to the sediment supplied from the Wang River (one of four major tributaries forming the Chao Phraya River).

The Ping River is considered as a mountainous river, which BL typically accounts for $20-40 \%$ of total sediment load [53]. In Thailand, the RID traditionally estimates the BL at about $23 \%$ of the total sediment load for water resources development planning and design [54]. Since the Ping River has unique sediment characteristics, estimating sediment flux using $23 \%$ as the BL fraction of the total sediment load may result in large uncertainty in the estimated sediment fluxes. Bed material of the upper mountainous reach was characterized by very coarse sand to pebble, but the BL was less than $1 \%$ of the total sediment load. In the lower basin with a gradient of $0.0004-0.0005$, the river is mainly composed of very coarse sand to coarse sand, but the sediment is primarily transported as BL (5-98\% of the total sediment load). In the river section, 90 to $220 \mathrm{~km}$ from the river outlet, $80-98 \%$ of the total sediment load was transported as bedload. Bidorn et al. [34] studied the sediment downstream of the Bhumibol Dam between 2011 and 2013. They reported that BL in the lower basin (at 40 to $200 \mathrm{~km}$ from the river outlet; between P.2A 
to P.17) had BL of $17-67 \%$ of total sediment load when river discharge ranged between 220 and $360 \mathrm{~m}^{3} / \mathrm{s}$. The average streamflow at this portion was $245-250 \mathrm{~m}^{3} / \mathrm{s}$ (Table 1) and criteria to estimate bedload at $23 \%$ of total sediment load should be carefully applied.

\subsection{Sediment Dynamics}

Results from long-term total sediment load study (Figure 8) and MK analyses at P.1, P.17, and C.2 (Table 2) were used to study the variation of sediment supplied from the Ping River Basin to the CPR since the recorded data covered pre-and post-construction of the Bhumibol Dam. Over a century of total sediment load data at P.1 revealed that the upper basin yielded annual total sediment load ranging 0.01-1.2 million $\mathrm{t} / \mathrm{y}\left(10^{6} \mathrm{t} / \mathrm{y}\right)$ with an average of $0.33 \times 10^{6} \mathrm{t} / \mathrm{y}$. Results from MK analysis showed decreasing trends in total sediment load in the upper basin. Figure 8 illustrates a declining tendency in total sediment load at P.1 since about 1982 (black solid line). However, a higher total sediment load than the average condition still occurred during high-water years (1970-1980) and flood events $(1995,2005$, and 2011). In the lower reach, the annual total sediment load between 1954 and 2019 at P.17 fluctuated at $0.2-2.7 \times 10^{6} \mathrm{t} / \mathrm{y}$. The average total sediment load of $0.8 \times 10^{6} \mathrm{t} / \mathrm{y}$ was greater than the sediment supplied from the upper basin. The time series of total sediment load at P.17 also revealed that even though the Bhumibol Dam had operated since 1964, the total sediment load at P.17 after dam construction was relatively higher than before the dam was built.

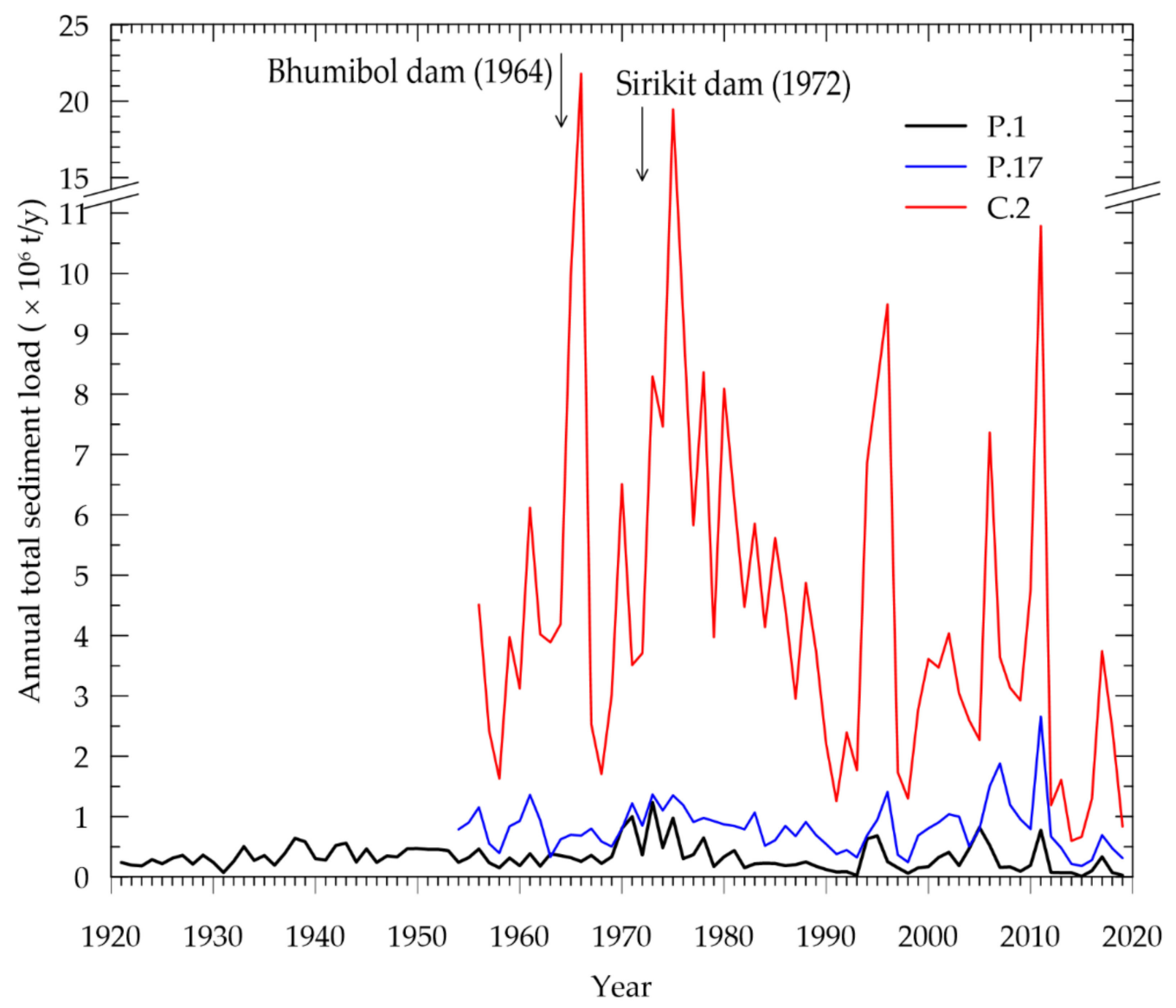

Figure 8. Time series of total sediment at Stations P.1, P.17 and C.2.

Regarding the MK analyses, total sediment load in the lower basin showed no statistical trends over the last 65 years. Moreover, in the lower basin, the annual total sediment load was more than that in the upper basin during the past 40 years. The Wang River 
merges with the Ping River $180 \mathrm{~km}$ upstream of P.17 as a source of sediment adding to the lower Ping River reach, as shown in observed data in 2019 (Table 2).

Based on the estimated total sediment load from 1956 to 2019, the annual total sediment load at C.2 ranged from $0.6-21.8 \times 10^{6} \mathrm{t} / \mathrm{y}$. The highest total sediment load of $21.8 \times 10^{6} \mathrm{t} / \mathrm{y}$ occurred in 1966 (a year after the Bhumibol Dam was completed). The total sediment load plummeted to $2.5 \times 10^{6} \mathrm{t} / \mathrm{y}$ in later years. However, the total sediment load tended to increase during high-water periods (1970-1980), even though another large dam, Sirikit Dam was operational in 1972. The total sediment load decreased from 1980 to 1990 but was apparently high when the extreme flooding events occurred. The CPR receives both water and sediment from its four tributaries, the Ping, Wang, Yom, and Nan Rivers (Figure 1). The Wang River merges with the Ping River before combining with the Nan River, which has the Yom as a tributary. The Wang River contributes about $16 \%$ of the Ping River discharge, and the water draining from the Yom River accounts for $40 \%$ of the Nan River flow [35,55-57]. The Ping and Nan Rivers form the CPR, accounting for $44 \%$ and $56 \%$ of the river flow of the $\mathrm{CPR}$, respectively $[35,57]$. The difference in sediment characteristics among these rivers has been reported by several previous studies $[34,40,48,54-58]$ that showed each river tends to contribute sediment to the CPR to a different degree. A comparison between the total sediment load at C.2 and P.17 provided sediment information supplied from the Wang and Ping Rivers to the CPR. Results indicated that the Ping River contributed a total sediment load of $16-44 \%$ to the CPR with $26 \%$ on average. Therefore, the Yom and Nan Rivers were likely the primary sources supplying sediment load to the CPR system. Hence, sediment regime changes in the Ping River may not dramatically affect sediment delivered to the CPR.

\subsection{Effect of the Bhumibol Dam on Sediment Supplied to the Chao Phraya River}

Damming is one of the possible causes of sediment load reduction in many rivers worldwide [1,7,9,31,59-62]. The Bhumibol Dam on the Ping River and the Sirikit Dam on the Nan River was estimated to cause a 75-85\% sediment reduction to the CPR system. However, the DMC of the total sediment load at P.1 (Figure 7a) indicated that the Ping River headwaters showed no significant changes in total sediment load from 1921 to 1970. A temporal increase of total sediment load occurred only during the high-water years and some major flood events. An apparent decline in DMC slope at P.1 was found after the 1980s. This decreasing trend compared to the pre-construction of the Bhumibol Dam likely indicated the effects of human activities such as water management to promote agricultural activities under the "Great Chao Phraya Project" [27]. The Bhumibol Dam was constructed in the middle Ping River Basin; thus, the effects of water impoundment by the dam should be observed in the lower basin. However, no obvious changes in the slope of the DMC at P.17 (Figure 7b) were recorded between 1954 and 2019.

In the lower basin, the DMC shift at P.17 corresponded to flood events. Results from river surveys in 2019 revealed that the upper Ping River Basin supplied low total sediment load due to river reach capacity and sediment sizes. Therefore, total sediment load supply to the middle basin was limited, as seen from the sediment data at P.73 (Table 1) and XP.10 (Table 2). Sediment data observed at PU02 indicated that very high SSL occurred $20 \mathrm{~km}$ downstream at P.73 due to sediment supplied from the Mae Chaem River. However, the Mae Chaem River contributes only about 30\% of the Ping River runoff, and the calculated daily SSL data using sediment rating curves developed from sediment samples at PU02 may be overestimated due to the location of the observation issue mentioned above (see Section 4.1). Field observations also revealed that the BL in the lower basin was obviously higher than SSL. The remarkably high total sediment load, especially BL, produced downstream from the Bhumibol Dam was likely caused by the many sand mines located along the lower stretches of the Ping River (Figure 9). High total sediment load was mainly produced in the lower basin, and the Bhumibol Dam is unlikely to be responsible for the changes in sediment supply from the Ping River to the 
CPR system. By contrast, sedimentation processes combined with sand mining along the lower reach of the river may be responsible for sediment supply to the CPR.

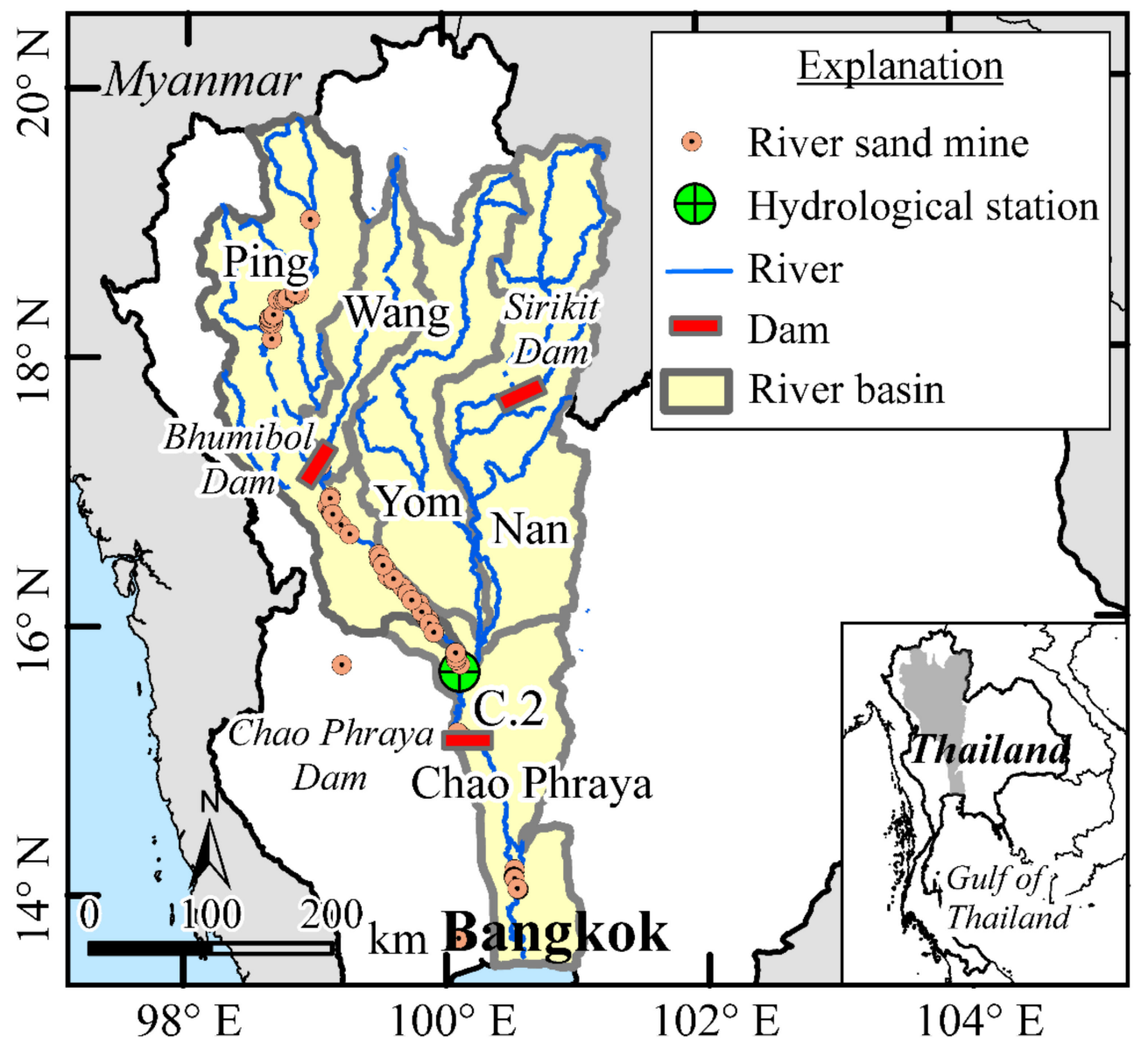

Figure 9. Location of sand mines along the Ping River.

The DMC of total sediment load at C.2 near the Chao Phraya River indicated an abrupt change in slope in 1964 (Figure 7c) after the Bhumibol Dam was completed. However, changes were also presented as rapid increases of total sediment load in 1965 and 1966, a year after dam construction. A temporary decline in total sediment load occurred between 1957 and 1972, before considerably increasing after the Sirikit Dam was constructed on the Nan River. The total sediment load value observed at C.2 increased (steeper slope than during the pre-dam construction period) between 1976 and 1994 when water management was intensely promoted. The decrease in total sediment load was also observed after the severe flood in 1995, and again after the Thailand Great Flood of 2011. This indicated that the degree of water management on the other tributaries, such as the construction of the Kiew Kho Ma Dam in the Wang River in 2008 (Figure 1), affected the DMC of P.17 (decline in slope after 2011 in Figure $7 \mathrm{~b}$ ). Water regulation by medium and small irrigation projects that have continuously expanded from 1995 to 2019 may also impact sediment supply to the Chao Phraya River system more than the Bhumibol Dam's construction.

\section{Conclusions}

We have presented the characteristics and variation of sediment loads in the Ping River Basin, the largest of the four major river basins of the Chao Phraya River system, Thailand. Historical river and sediment data for the last half-century were combined with systematic river and sediment measurement data recorded in 2019 to analyze and assess the sediment reduction supplied to the Chao Phraya River as a result of the Bhumibol Dam 
construction. Results revealed that Ping River behavior differs from general mountainous rivers. The upper and middle river reaches are characterized by very coarse sand to pebbles $\left(0.5<\mathrm{d}_{50}<10 \mathrm{~mm}\right)$, while the sediment was mainly transported in suspension $(\mathrm{BL}<3 \%$ of SSL). By contrast, the lower reach of the Ping River is comprised of medium to coarse sand with $\mathrm{d}_{50}$ ranging between 0.4 and $1.7 \mathrm{~mm}$ and sediment mainly transported as BL (5-98\% of the total sediment load). Historical river flow and sediment data recorded from 1921 to 2019 suggested that daily SSL along the Ping River correlated well with daily streamflow $\left(\mathrm{R}^{2}>0.72\right)$, while daily SSL at a gaging station in the Chao Phraya River strongly correlated with daily streamflow during the wet season $\left(R^{2}=0.89\right)$.

Results from long-term total sediment load analysis indicated that the upper basin yields a total sediment load of $900 \mathrm{t} / \mathrm{d}$, while the total sediment load in the middle basin, which was greater than in the upper basin, was mainly trapped by the Bhumibol Dam. The total sediment load in the lower basin was greater than in the upper Ping River Basin, with average values of 2235 and $2300 \mathrm{t} / \mathrm{d}$ for pre- and post-construction of the Bhumibol Dam, respectively. Thus, while the dam does effectively trap sediment, there was only a $5 \%$ reduction in sediment load at the river outlet because of other sediment sources. This includes the Wang River, another major river basin in the Chao Phraya River System, which drains its sediment to the Ping River $50 \mathrm{~km}$ downstream of the Bhumibol Dam. The DMC plots of total sediment load also indicated no significant change in sediment yield due to the construction of the Bhumibol Dam. Based on the sediment analysis results, the Ping River contributes about $26 \%$ of the total sediment load recorded near the confluence of the Chao Phraya River (Station C.2). The sediment load in the Ping River is mainly dominated by the sediment processes in the lower Ping River Basin. Therefore, the construction of the Bhumibol Dam had only a slight impact on the sediment supply from the Ping River to the Chao Phraya River system and, ultimately, the coastal system of the Chao Phraya Delta.

Supplementary Materials: The following are available online at https:/ / www.mdpi.com/2073-444 1/13/3/386/s1, Figure S1. Sediment rating curves at eight hydrological stations: (a) P.75; (b) P.67; (c) P.1; (d) P.73; (e) PU02; (f) P.2a; (g) P.17; (h) C.2., Figure S2. Time series of total sediment load at RID stations along the Ping River., Figure S3. Photographs illustrate turbidity degree of water observed downstream the Bhumibol Dam: (a) XP.13 taken on 23 Feb 2019 (dry season); (b) XP.13 taken on 9 July 2019 (wet season); (c) XP.16 taken on 25 Feb 2019 (dry season); (d) XP.16 taken on 11 July 2019 (wet season).

Author Contributions: Conceptualization, M.N. and B.B.; methodology, M.N., W.C. and S.S.; formal analysis, M.N. and B.B.; investigation, B.B., W.C. and W.C.B.; writing-original draft preparation, M.N.; writing-review and editing, B.B. and W.C.B.; supervision, W.C.B.; project administration, B.B.; funding acquisition, B.B. All authors have read and agreed to the published version of the manuscript.

Funding: This research was funded by Chulalongkorn University, grant number GB-B_62_011_21_05 and Office of the Higher Education Policy, Science, Research and Innovation National Council (NRCT) by Human Resource Development and Management Unit and Funding for the Development of Higher Education Institutions Research and Innovation Creation, grant number B05F630024.

Institutional Review Board Statement: Not applicable.

Informed Consent Statement: Not applicable.

Acknowledgments: The authors acknowledge the support of the RID for providing the river datasets used in this study. The authors acknowledge also the support of the 100th Anniversary Chulalongkorn University Fund for Doctoral Scholarship, the 90th Anniversary Chulalongkorn University Fund (Ratchadaphiseksomphot Endowment Fund: GCUGR1125633037D). We thank two anonymous reviewers and an academic editor who provided many insightful comments.

Conflicts of Interest: The authors declare no conflict of interest. 


\section{References}

1. Liu, S.W.; Zhang, X.F.; Xu, Q.X.; Liu, D.C.; Yuan, J.; Wang, M.L. Variation and driving factors of water discharge and sediment load in different regions of the Jinsha River basin in China in the past 50 years. Water 2019, 11, 1109. [CrossRef]

2. Wang, H.; Saito, Y.; Zhang, Y.; Bi, N.; Sun, X.; Yang, Z. Recent changes of sediment flux to the western Pacific Ocean from major rivers in East and Southeast Asia. Earth Sci. Rev. 2011, 108, 80-100. [CrossRef]

3. Peng, J.; Chen, S.; Dong, P. Temporal variation of sediment load in the Yellow River basin, China, and its impacts on the lower reaches and the river delta. CATENA 2010,83, 135-147. [CrossRef]

4. Giosan, L.; Syvitski, J.; Constantinescu, S.; Day, J. Protect the world's deltas. Nature 2014, 516, 31-33. [CrossRef] [PubMed]

5. Yang, H.F.; Yang, S.L.; Xu, K.H.; Milliman, J.D.; Wang, H.; Yang, Z.; Chen, Z.; Zhang, C.Y. Human impacts on sediment in the Yangtze River: A review and new perspectives. Glob. Planet. Change 2018, 162, 8-17. [CrossRef]

6. Syvitski, J.P.M.; Kettner, A.J.; Overeem, I.; Hutton, E.W.; Hannon, M.T.; Brakenridge, G.R.; Day, J.; Vorosmarty, C.; Saito, Y.; Giosan, L.; et al. Sinking deltas due to human activities. Nat. Geosci. 2009, 2, 681-686. [CrossRef]

7. Panda, D.K.; Kumar, A.; Mohanty, S. Recent trends in sediment load of tropical (Peninsular) river basins of India. Glob. Planet. Change 2011, 75, 108-118. [CrossRef]

8. Syvitski, J.P.M.; Saito, Y. Morphodynamics of deltas under the influence of humans. Glob. Planet. Change 2007, 57, 261-282. [CrossRef]

9. Walling, D.E. Human impact on land-ocean sediment transfer by the world's rivers. Geomorphology 2006, 79, 192-216. [CrossRef]

10. Walling, D.E.; Fang, D. Recent trends in the suspended sediment loads of the world's rivers. Glob. Planet. Change 2003, 39, 111-126. [CrossRef]

11. He, Y.; Gui, Z.; Su, C.; Chen, X.; Chen, D.; Lin, K.; Bai, X. Response of sediment load to hydrological change in the upstream part of the Lancan-Mekong River over the past 50 years. Water 2018, 10, 888. [CrossRef]

12. Wang, Y.; Rhoads, B.L.; Wang, D.; Wu, J.; Zhang, X. Impacts of large dams on the complexity of suspended sediment dynamics in the Yangtze River. J. Hydrol. 2018, 558, 184-195. [CrossRef]

13. Milliman, J.D.; Meade, R.H. World-Wide delivery of river sediment to the oceans. J. Geol. 1983, 91, 1-21. [CrossRef]

14. Milliman, J.D.; Syvitski, J.P.M. Geomorphic/Tectonic control of sediment discharge to the ocean: The importance of small mountainous rivers. J. Geol. 1992, 100, 525-544. [CrossRef]

15. Jiang, C.; Zhang, L.; Li, D.; Li, F. Water discharge and sediment load changes in China: Change patterns, causes, and implications Water 2015, 7, 5849-5875. [CrossRef]

16. Yang, S.L.; Xu, K.H.; Milliman, J.D.; Yang, H.F.; Wu, C.S. Decline of Yangtze River water and sediment discharge: Impact from natural and anthropogenic changes. Sci. Rep. 2015, 5, 1-4. [CrossRef]

17. Yu, Y.; Shi, X.; Wang, H.; Yue, C.; Chen, S.; Liu, Y.; Hu, L.; Qiao, S. Effects of dams on water and sediment delivery to the sea by the Huanghe (Yellow River): The special role of water-sediment modulation. Anthropocene 2013, 3, $72-82$.

18. Wang, H.; Bi, N.; Saito, Y.; Wang, Y.; Sun, X.; Zhang, J.; Yang, Z. Recent changes in sediment delivery by the Huanghe (Yellow River) to the sea: Causes and environmental implications in its estuary. J. Hydrol. 2010, 391, 302-313. [CrossRef]

19. Hoffmann, T.; Thorndycraft, V.R.; Brown, A.G.; Coulthard, T.J.; Damniati, B.; Kale, V.S.; Middelkoop, H.; Notebaert, B.; Walling, D.E. Human impact on fluvial regimes and sediment flux during the Holocene: Review and future research agenda. Glob. Planet. Change 2010, 72, 87-98. [CrossRef]

20. Syvitski, J.P.M.; Vörösmarty, C.J.; Kettner, A.J.; Green, P. Impact of humans on the flux of terrestrial sediment to the global coastal ocean. Science 2005, 308, 376-380. [CrossRef]

21. Tessler, Z.D.; Vörösmarty, C.J.; Grossberg, M.; Gladkova, I.; Aizenman, H.; Syvitski, J.P.M.; Georgiou, E.F. Profiling risk and sustainability in coastal deltas of the world. Science 2015, 349, 638-643. [CrossRef] [PubMed]

22. Mikhailov, V.N.; Mikhailova, M.V. Impact of local water management and hydraulic-engineering projects on river deltas. Water Resour. 2015, 42, 275-284. [CrossRef]

23. Syvitski, J.P.; Kettner, A. Sediment flux and the anthropocene. Philos. Trans. R. Soc. A Math. Phys. Eng. Sci. 2011, 369, 957-975. [CrossRef] [PubMed]

24. Vanmaercke, M.; Poesen, J.; Govers, G.; Verstraeten, G. Quantifying human impacts on catchment sediment yield: A continental approach. Glob. Planet. Change 2015, 130, 22-36. [CrossRef]

25. Kuehl, S.A.; Yang, S.; Yu, F.; Copard, Y.; Liu, J.; Nittrouer, C.A.; Xu, J. Asia's mega rivers: Common source, diverse fates. Eos 2020, 1-8. [CrossRef]

26. Tanabe, S.; Saito, Y.; Sato, Y.; Suzuki, Y.; Sinsakul, S.; Tiyapairach, S.; Chaimanee, N. Stratigraphy and holocene evolution of the mud-dominated Chao Phraya delta, Thailand. Quat. Sci. Rev. 2003, 22, 789-807. [CrossRef]

27. Vongvissessomjai, S. Chao Phraya Delta: Paddy field irrigation areas in tidal deposits. In Proceedings of the the 56th International Executive Council of ICID, Beijing, China, 10-18 September 2005.

28. Japan International Cooperation Agency (JICA). The Feasibility Study on Mangrove Revival and Extension Project in the Kingdom of Thailand; Final Report; Ministry of Agrilture: Bangkok, Thailand, 2000.

29. Winterwerp, J.C.; Borst, W.G.; De Vries, M.B. Pilot study on the erosion and rehabilitation of a mangrove mud coast. J. Coast. Res. 2005, 21, 223-230. [CrossRef]

30. Uehara, K.; Sojisuporn, P.; Saito, Y.; Jarupongsakul, T. Erosion and accretion processes in a muddy dissipative coast, the Chao Phraya River delta, Thailand. Earth Surf. Process. Landf. 2010, 35, 1701-1711. [CrossRef] 
31. Gupta, H.; Kao, S.J.; Dai, M. The role of mega dams in reducing sediment fluxes: A case study of large Asian rivers. J. Hydrol. 2012, 464-465, 447-458. [CrossRef]

32. Milliman, J.D.; Farnsworth, K.L. River Discharge to the Coastal Ocean: A Global Synthesis; Cambridge University Press: New York, NY, USA, 2011; p. 382.

33. Office of Natural Resources and Environmental Policy and Planning. Developing Watershed Management Organizations in Pilot Sub-Basins of the Ping River Basin; Final Report; Office of Natural Resources and Environmental Policy and Planning: Bangkok, Thailand, 2005.

34. Bidorn, B.; Kish, S.A.; Donoghue, J.F.; Bidorn, K.; Mama, R. Sediment transport characteristic of the Ping River basin, Thailand. Procedia Eng. 2016, 154, 557-564. [CrossRef]

35. Hydro and Agro Informatics Institute (HAII). Report on Data Collection and Analysis: Database Development Project and Flood and Drought Modeling of 25 River Basins (Ping River Basin); Hydro and Agro Informatics Institute (HAII): Bangkok, Thailand, 2012. (In Thai)

36. Sharma, D.; Gupta, A.D.; Babel, M.S. Spatial disaggregation of bias-corrected GCM precipitation for improved hydrologic simulation: Ping River Basin, Thailand. Hydrol. Earth Syst. Sci. 2007, 11, 1373-1390. [CrossRef]

37. Wood, S.H.; Ziegler, A.D. Floodplain sediment from a 100-year-recurrence flood in 2005 of the Ping River in northern Thailand. Hydrol. Earth Syst. Sci. 2008, 12, 959-973. [CrossRef]

38. Ziegler, A.D.; Sidle, R.C.; Phang, V.X.H.; Wood, S.H.; Tantasirin, C. Bedload transport in SE Asian streams-Uncertainties and implications for reservoir management. Geomorphology 2014, 227, 31-48. [CrossRef]

39. Manee, D.; Tachikawa, Y.; Yorozu, K. Analysis of hydrologic variable changes related to large scale reservoir operation in Thailand. J. Jpn. Soc. Civ. Eng. 2015, 71. [CrossRef]

40. Bidorn, B.; Kish, S.A.; Donoghue, J.F.; Huang, W.; Bidorn, K. Variability of the total sediment supply of the Chao Phraya River, Thailand. In River Sedimentation, Proceedings of the 13th International Symposium on River Sedimentation, Stuttgart, Germany, 19-22 September 2016; CRC Press: Boca Raton, FL, USA, 2016; p. 23.

41. Mann, H.B. Nonparametric tests against trend. Econometrica 1945, 13, 245-259. [CrossRef]

42. Kendall, M.G. Rank Correlation Methods, 4th ed.; Charles Griffin: London, UK, 1975.

43. Shi, H.; Hu, C.; Wang, Y.; Liu, C.; Li, H. Analyses of trends and causes for variations in runoff and sediment load of the Yellow River. Int. J. Sediment Res. 2017, 32, 171-179. [CrossRef]

44. Yue, X.; Mu, X.; Zhao, G.; Shao, H.; Gao, P. Dynamic changes of sediment load in the middle reaches of the Yellow River basin, China and implications for eco-restoration. Ecol. Eng. 2014, 73, 64-72. [CrossRef]

45. Yue, S.; Wang, C.Y. Applicability of prewhitening to eliminate the influence of serial correlation on the Mann-Kendall test. Water Resour. Res. 2002, 38, 4-1-4-7. [CrossRef]

46. Mama, R.; Jung, K.; Bidorn, B.; Namsai, M.; Feng, M. The local observed trends and variability in rainfall indices over the past century of the Yom River Basin, Thailand. J. Korean Soc. Hazard Mitig. 2018, 18, 41-55. [CrossRef]

47. Zhang, J.; Zhang, X.; Li, R.; Chen, L.; Lin, P. Did streamflow or suspended sediment concentration changes reduce sediment load in the middle reaches of the Yellow River? J. Hydrol. 2017, 546, 357-369. [CrossRef]

48. Namsai, M.; Bidorn, B.; Chanyotha, S.; Mama, R.; Phanomphongphaisarn, N. Sediment dynamics and temporal variation of runoff in the Yom River, Thailand. Int. J. Sediment Res. 2020, 35, 365-376. [CrossRef]

49. Zhang, S.; Lu, X.X.; Higgitt, D.L.; Chen, C.T.A.; Han, J.; Sun, H. Recent changes of water discharge and sediment load in the Zhujiang (Pearl River) Basin, China. Glob. Planet. Change 2008, 60, 365-380. [CrossRef]

50. Li, Z.; Xu, X.; Yu, B.; Xu, C.; Liu, M.; Wang, K. Quantifying the impacts of climate and human activities on water and sediment discharge in a karst region of Southwest China. J. Hydrol. 2016, 542, 836-849. [CrossRef]

51. Rachlewicz, G.; Zwoliński, Z.; Kociuba, W.; Stawska, M. Field testing of three bedload samplers' efficiency in a gravel-bed river, Spitsbergen. Geomorphology 2017, 287, 90-100. [CrossRef]

52. Lemma, H.; Nyssen, J.; Frankl, A.; Poesen, J.; Adgo, E.; Billi, P. Bedload transport measurements in the Gilgel Abay River, Lake Tana Basin, Ethiopia. J. Hydrol. 2019, 577, 123968. [CrossRef]

53. Turowski, J.M.; Rickenmann, D.; Dadson, S.J. The partitioning of the total sediment load of a river into suspended load and bedload: A review of empirical data. Sedimentology 2010, 57, 1126-1146. [CrossRef]

54. Royal Irrigation Department (RID). The Relation between Suspended Sediment and Drainage Area in 25 River Basins; Royal Irrigation Department (RID): Bangkok, Thailand, 2012. (In Thai)

55. Hydro and Agro Informatics Institute (HAII). Report on Data Collection and Analysis: Database Development Project and Flood and Drought Modeling of 25 River Basins (Wang River Basin); Hydro and Agro Informatics Institute (HAII): Bangkok, Thailand, 2012. (In Thai)

56. Hydro and Agro Informatics Institute (HAII). Report on Data Collection and Analysis: Database Development Project and Flood and Drought Modeling of 25 River Basins (Yom River Basin); Hydro and Agro Informatics Institute (HAII): Bangkok, Thailand, 2012. (In Thai)

57. Hydro and Agro Informatics Institute (HAII). Report on Data Collection and Analysis: Database Development Project and Flood and Drought Modeling of 25 River Basins (Nan River Basin); Hydro and Agro Informatics Institute (HAII): Bangkok, Thailand, 2012. (In Thai) 
58. Bidorn, B.; Chanyotha, S.; Kish, S.A.; Donoghue, J.F.; Bidorn, K.; Mama, R. The effects of Thailand' s great flood of 2011 on river sediment discharge in the upper Chao Phraya River basin, Thailand. Int. J. Sediment Res. 2015, 30, 328-337. [CrossRef]

59. Wu, C.; Ji, C.; Shi, B.; Wang, Y.; Gao, J.; Yang, Y.; Mu, J. The impact of climate change and human activities on streamflow and sediment load in the Pearl River basin. Int. J. Sediment Res. 2019, 34, 307-321. [CrossRef]

60. Zuliziana, S.; Tanuma, K.; Yoshimura, C.; Saavedra, O.C. Distributed model of hydrological and sediment transport processes in large river basins in Southeast Asia. Hydrol. Earth Syst. Sci. 2015, 12, 6755-6797.

61. Li, D.; Lu, X.X.; Yang, X.; Chen, L.; Lin, L. Sediment load responses to climate variation and cascade reservoirs in the Yangtze River: A case study of the Jinsha River. Geomorphology 2018, 322, 41-52. [CrossRef]

62. Guo, L.P.; Mu, X.M.; Hu, J.M.; Gao, P.; Zhang, Y.F.; Liao, K.T.; Bai, H.; Chen, X.L.; Song, Y.J.; Jin, N.; et al. Assessing impacts of climate change and human activities on streamflow and sediment discharge in the Ganjiang River Basin (1964-2013). Water 2019, 11, 1679. [CrossRef] 